NASA Technical Memorandum 81440

(WASA-TH-81449) LUBRICATION OP

BOLLI WLC-ELEMENT BEARINGS (NASA)

HC: $103 / 118 \triangle 01$

26

CSCL 131
N80-20591

$63 / 37 \quad \begin{aligned} & \text { Onclas } \\ & 47610\end{aligned}$

\title{
LUBRICATION OF ROLLING-ELEMENT BEARINGS
}

Richard J. Parker

Lewis Researc.i Center

Cleveland, Ohio

Prepared for the

International Lubrication Conference

cosponsored by the American Society of Mechanical Engineers

and the American Society of Lubrication Engineers

San Francisco, California, August 18-21, 1980 
LUBRICATION OF ROLLING ELEMENT BEAKINGS

Richard J. Parker

National Auronautics anu Spact Administration

Lew is Research Center

Cleveland, onto

AGSTRACT

This paper is a broas survey of the lubrication of rolling-element bearings. Emphasis is on the critical design aspects related to speed, temperature, and ambient pressure environment. Types of lubrication inluoing grease, jets, mist, wick, and through-the-race are discussed. The paper covers the historical development, present state of technoloyy, and the future problems of rolling-element bearing lubrication.

\section{INTROUUCTION}

In this survey of the lubrication of rolling-element bearinys, all the common niethods of lubrication are discussed. For the great bulk of bearings in industrial machinery, well def ined procedures for designing sat istactory lubrication systents are avallable in manutacturers' catalogs and standard handbooks. The discussions on these more common methods are rather brief in this paper. The aircratt gas turbine engine has provided the impetus and ariving force for quantum leaps in lubrication technclogy. For that reason, this paper leans heavily toward discussions of that technology.

\section{FUNCTIUNS OF A, LIQUIO LUBRICANT}

A liquiu or grease lubricant in a rolling-element bearing provides several functions. A major function is to separate the surf aces of the raceways and the rolling elements with an elastohydrodynamic (EHO) $+11 \mathrm{~lm}$. The formation of the EHO $f\{$ lin devends on the elastic deformation of the contactiny surtaces and the hydrodynanic properties of the lubricant. The magnitude of the EHU $f(i \mathrm{~m}$ is dependent mainly on the viscusity of the lubricant and the speed and load conditions on the bearing. For nurmal bearing geometries, the maynitude of the F.HO $\mathrm{film}$ thickness is of the order of 0.1 to 1.0 micron $(4$ to $40 \mu \mathrm{in.}$ ).

It was only about 30 years ayo that it was recognized that a lubricant in the form of an EHU filin could separaty heavily loaded contacts in rolling-element bearings. Grubin L 1 jl in ly4y developed an approxinate $111 \mathrm{~m}$ thickness equation for EHD line cuntacts. It was the mid-1950's before the first experimental evidence of an EHO $f i$ in was obtainea. in 1958 Crook [2]

Tumbers in brackets denote references at end of paper. 


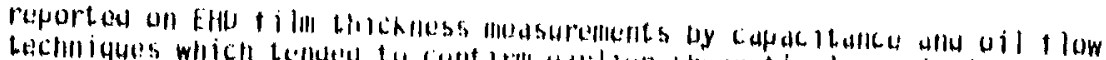

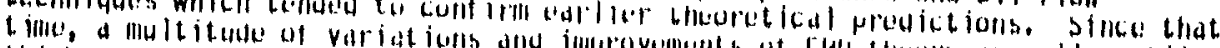
thickmess likesulements have been pablished.

surtaces is not

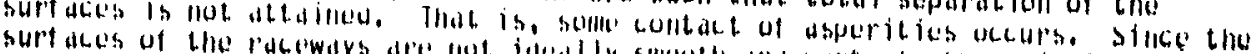

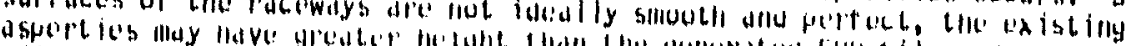

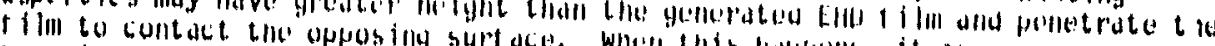

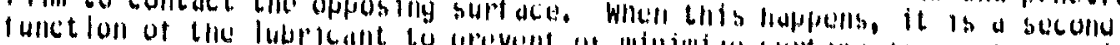

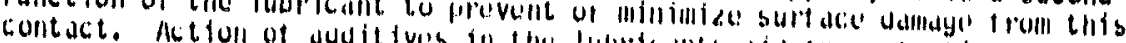

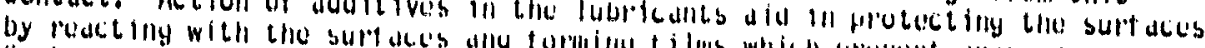

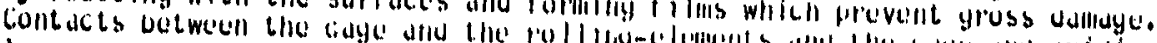

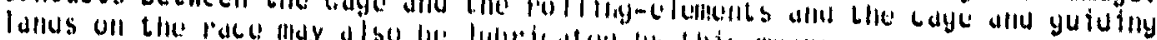

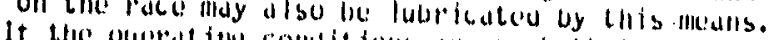

trequent alle bustallug conditions dre such that the asperity contalis are

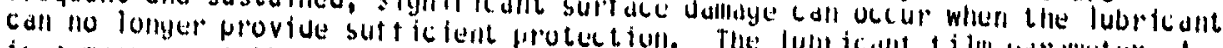

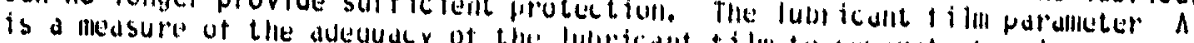

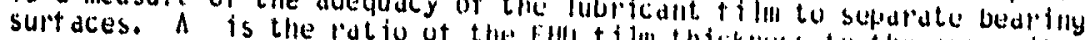
roughness 0 , where 0 a $\sqrt{0}+$. roughness ot tile two surtaces of of and of dila of are the RAS asperity contacts betweell the rolling surt In urder for the trefuency of gredter thall 3 . Whin surtace damage and short is lluch less thall l, one should expect siginit icant and 3 , solle asperity cuntact orite. When $A$ is butiveen apploximatel. 1.5 can be obtained due to the protect discussiun on tallure nuues ans a later section of this paper.

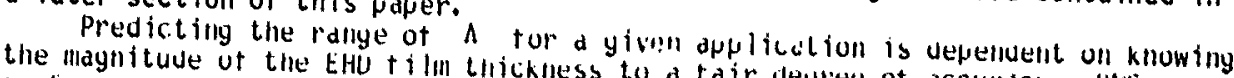
surtace roughness can, of course, beess to a tair deyree of accurdcy. KMS durilly run-in. The Ehu t illinse, be measured but lllay be modit lea soinewhat equations. All eas $j$ ty apulin thickntes can be calculated by une of severd either point or line contacts is

$$
H_{\text {min }}=3.63 \mathrm{u}^{0.68 \mathrm{j}_{\mathrm{j}} 0.49_{w_{j}} 0.0 \% 3}\left(1-\mathrm{e}^{-0.68 \mathrm{k}}\right)
$$

where $H_{111}$ is the dimensionless minimum $t /$ lm thickiess and $k$ is a simplitied expiession tor the ellipticity pardoler

$$
k=1.03\left(\frac{k_{y}}{R_{x}}\right)^{0.64}
$$

The other terms are vet ined in the appendix. Convenient relations tor determining the eftective reaif ot curvature allu
surtace velocities are yiven by Alluerson in $14 j$ for both ball and cy? indrical
roller bearings.

Liquta

Heat generated in a bedriny can be renurenctions in rollingwelentint bedrings. through the bedring either to an extelloved it the lubricant is circulated contal with the systencesilly or housing. heat exchanger or simply brought into recirculating lubricant systems will be ging cooling techniques with also tlushes vut wedr vetbris liquid lubricants dind greases can dct ds rust contact in the badring. Buth help to seal out uirt, uust. and de istureast alla currosion preventatives and

\section{SULIU FILM LUBRILATIUN}

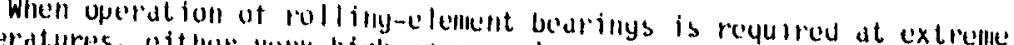
temperdtures, cither very high or very luw or at luw liquid lubricants or yrease's dre nut usualiy or at lew pressures (vacuam), norina I are vee to therind or oxidative instability of the lubricall. At low 


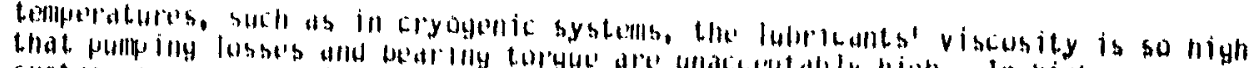

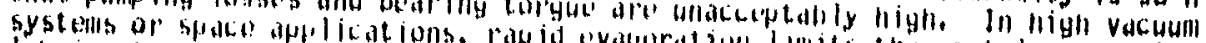
labticallts alla grivases. For these hllusud

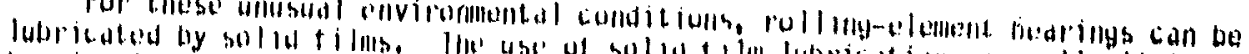

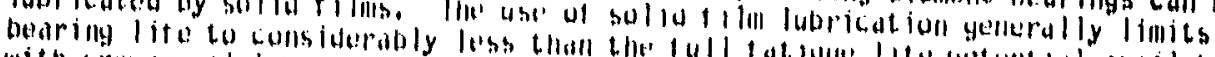

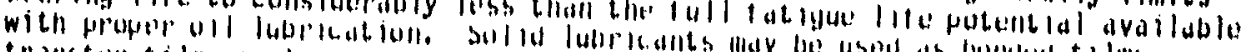

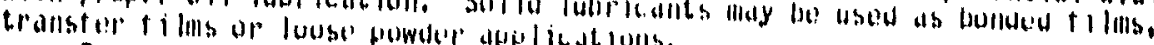

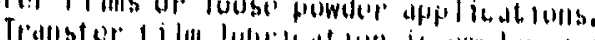

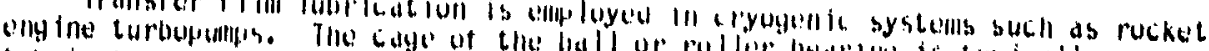

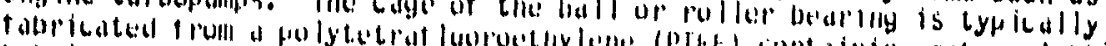

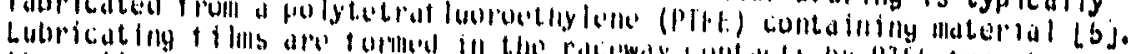

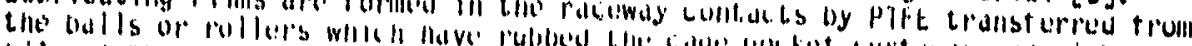

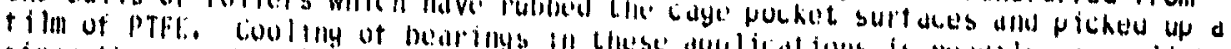

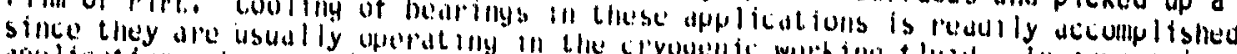

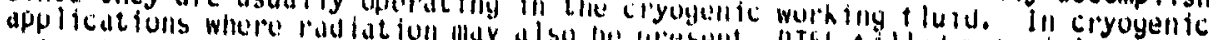

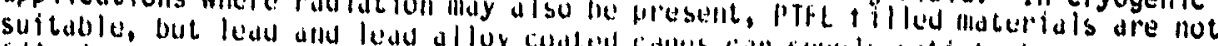
flial lubrication loj. In very intoh $[$ enpe

bonded tilms, has fruvide some dpplicatiuns, labrication with louse powders or disulphide, lead munoxide, and veyres or success. Puwders such as molybdenum

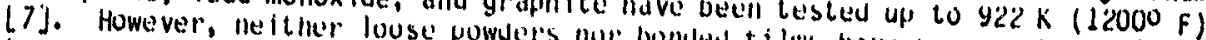
temperature rolling-element beariny lubrication. tilins have seen much use in high

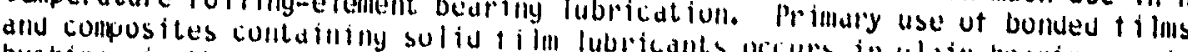
bushings in the delospde industry. Furticants vccurs in plain bearings and lubrication cian be tound in 18 and $y$ further discussiuns ot solid $t$ ilim

\section{LRLASE LUBKILATION}

Perhaps the most common, widely used, most simple, and most inexpens ive mode of lubrication for rolling-element bedrings is grease lubrication. sybthetic oil and a thickener. Adula phase of either a petroleun oil or a but getlerdlly ill larger yuallities. The lubricating process of $a$.

Jescribed in the literature in a jrease in a rolling-element bearing has been thickener phase acts assentially as a spot is perhaps oversinplified. The lubricating tluid. In all operating rollinger reservoir to hola the generally channels or is moved out of fling-element bearing, the grease and a portion of the tluid phase bleads finto path of the rolling balls or rollers lubricating tunction. Searlett

He found that the attempted to ubserve the mechanism ot grease lubrication. raceways appeared to be grease in which areas of the balls or rollers and the structur. due to its berng severe which the thickeniv had broken down in lubricat.ng tluid above. Also, ds shorked. This iluid did not resemble the thickness with grease voes not react to by uysun and wilson $111 j$, the the tiln from the lubricating fluid doled to changes in speed as would be expected lubricating mechanisin with grease. It appedics that some more complicated understand and be able. to predict the the thes that more work must be done to ciredse lubrication is geact the EHU t illil loming llature of yrease. bearing applications, although some of the more more moderate rolling-element

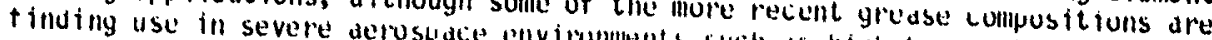
vacuum of space. The lllajur davant ayes ot such ds high tenperature and the bedring are similicity of vesign, case of a grease lubricated rolling-elentent space requifements.

Greases are retained within the be, ring, thus they wo not remove wear

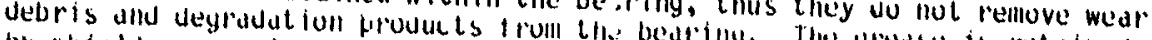
by shielas or seals of by the design of bearing. The grease is retallied efther add to the lied gencirated in

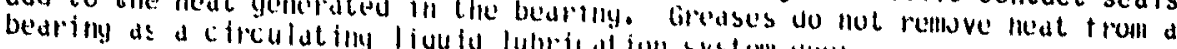

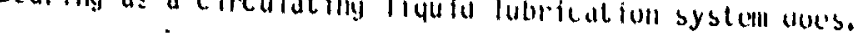


The speed limitatiuns ut yruabe lubricatce bearings are we mailly to lillited capacity to wissipate heat, but are diso at fectud oy bearilly typo anu cage tywe, Standara quality (ABt -1 or 3 ) ball and cyliriarical roller dearings with stallped stuel cages aru gunerally limited to 0.2 to 0.3 million uN. (ON is

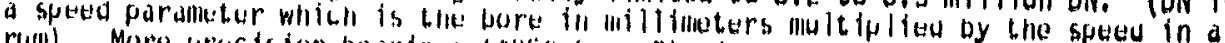

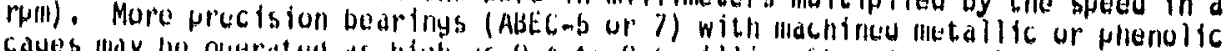
cayes may be operated as high as 0.4 to 0.6 millifon $0 N$. Grease lubricated tapered rollur bearings alla spherical roller bearings aro bonerally fimited to luss than U.2 million UN and U.I millifun UN, rospectively. These limits are basically those stated in bearing mantut acturers cataloys. Auditiunal discussion of uses allu limitations of grease lubrication in rollifly-e lenent bearings is tound in [10].

The selection of type or classitication of yredse, by buth cunsistency and type of thicketier, is based on the lonpuratures, speeds, and pressures to which the bearings are to be exposed. A curliprehensive discusston of yrease types ano collyositions can be tound in reterence L12. Fur most applicaliuns, the rolling-element bearing manufacturer call recomment the type of grease and in some cases can supply bearlilys prelubricated with the recommenued grease. Although in illany cases a piece of equipilient with yrease lubricated ba roller bearings may be describeu ds "sealed for life" or "lubricated for life," it should not be assumed that grease lubricateu vearings have int inite yrease than that of une iniply that that piece of equipment has a usetul life less than that of the yrease lubricated bearilly. Un the contrary, grease in an operating rolling-element bearing has d linite lite which indy be less than the calculated tatigue lite of the bearing. Grease lite is linjted by evaporation, degradation, andor leakage of the tluiu from the yrease. To preclude bearing failure due to indequate lubrication or worn out yrease, periodic relubrication should be scheduled.

The periou of reblubrication is genterally vased un experience with known or similiar systellis. An equation est lillating grease life in ball bearinys has been published by Booser $[13]$. The basis for the equation is a compilation of life tests on many sizes of bearinys in electric motors. Factors in the equation account for type of grease, size of bearing, temperature, speed, and load. With a combination of operatiny experience and trends trom the Booser equation, a satisfactory relubrication schedule can generdlly be applied. When possible it inanuf acturers, since relubrtcatication intervals recommended by equipment inanuf acturers, since relubrtcation shoulu be based on representative grease life
experience.

\section{JET LUBRICATION}

For rolling-element bearing applications where speeus are too high for grease or simple splash lubrication, jet lubrication is trequently usea to lubricate and control bearing temuerature by removing generated heat. In jet lubrication, the placellient of the nozzles, number of nozzles, jet velocity, vicricant flow rates, and removal of lubricant trom the bearing and immeuiate vicinity are all very important for satistactory operation. Even the internd? bearing design is a tactor to be considered.

The importance of caretul and proper jet lubricating systen design was shown by Matt and Giannutti $114 j$ and is summarized in Fig. 1. For seeminyly drastic difterence in bearing operation of load, speed anu lubricant tow rates, crastic difterence in bearing operation asu tenperature can be seen. In the low rate due to use ut lines, temperature rises urastically with increased bearing inner ring and a siniple oil jet directed at the loaded side of the ball solid lines, properly placequate scavenge port size. For the case shown by the external scavenge external scavenge pump allowed a decrease in temperature with increased lubricant tlow rate to an optimulin level. It is ubvious that some care must be taken in aesigning a jet lubricated bearing system.

The pruper placement of jets should take advantaye of any natural puming ability of the bearings. This is illustrated in Fig. 2 for d bali bedring with relieved rings and tor a tapered roller bearing. Centrituyd forces did in moving the vil through the beoring to coul and lubricate the elemerts. 


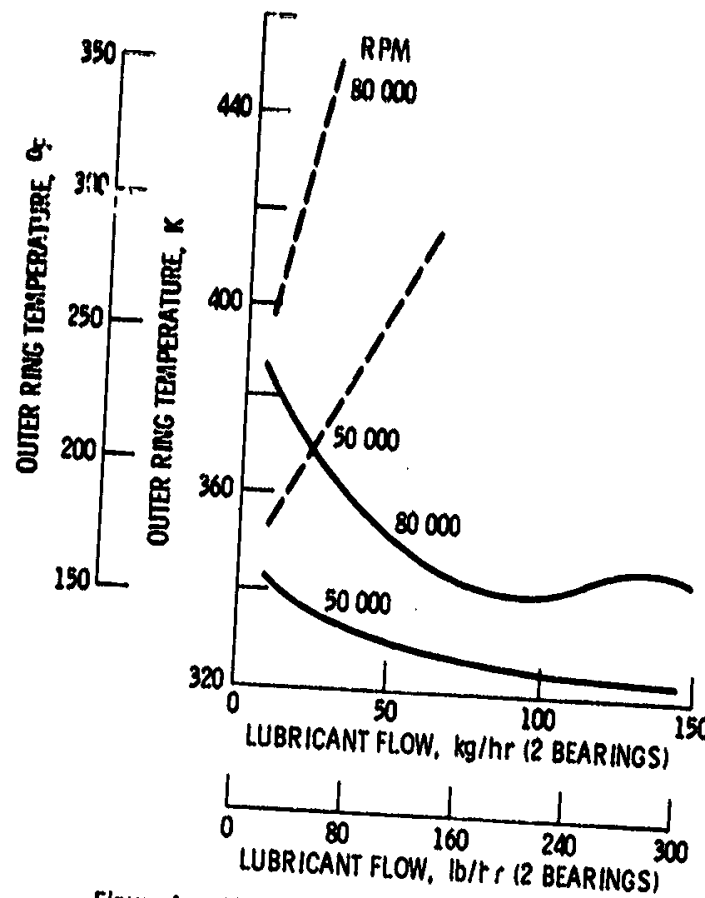

Figure 1. - Effectiveness of proper jet lubrication. Solld line denotas multiple, with adequate scavenge jet with inadequate scavengased line denoles single bore angular contact bavenge. (Test bearings, $20 \mathrm{~mm}$ $(50$ 1b); from (1141.) ball bearings; thrust load, $222 \mathrm{~N}$

Oirecting jets in the radial gaps between the rings and the cage is on the rings greatiglon of the cage and the lubrication of its surtaces bearings. The cage has been the high speed performance of jet lubrices sliding bearing with imaroper luben typically the first eleme of jet lubricated

it is shomn ther lubrication.

cages yive lower bearing temperatures ind jet lubrication outer-ring-riding inner-ring-riding cages. It is expected that with her speed capability than penetration and radial gap is between the inner ring and conflicting and thus better cooling of the bearing is and the cage, better [17] which shows exists, huwever, for 120-nnm- 4.7244 intaines. Some This difference cooler bearing temperature with an inner- $)$ bore ball bearings dubricant jet velocity is of
Lifed.

size. Miyakawa [1b], in experinents with, dependent on flow rate and nozzle signif fcant effects on bering-riding cages, showed that jot ${ }^{2}-1$ bore deep groove velocities greater on bearing temperature. Figure 3 trom velocity has $(66 \mathrm{ft} / \mathrm{sec})$ are required $10 \mathrm{~m} / \mathrm{sec}(33 \mathrm{tt} / \mathrm{sec})$ and preferably 15 ] shows that jet penetration rat io is ired for good penetration and cooling of to the totalo is the ratio of lubricant fluw transing of the bearing. The It has been shown flow trun the jet nozzle.

of nozzles, jet velocities and adequate scaveering and cage design, placement Likewtse for used for small bore ball bearings to jet lubrication can be attainable. For large ball bearings $117 \mathrm{~J}$. speeds to 20 up to $3.0 \mathrm{mill}$ ion 0 .

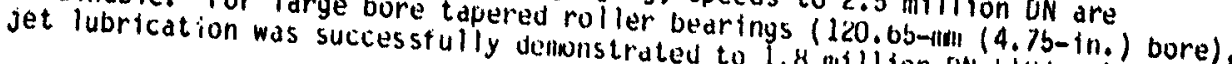


QUTER RING

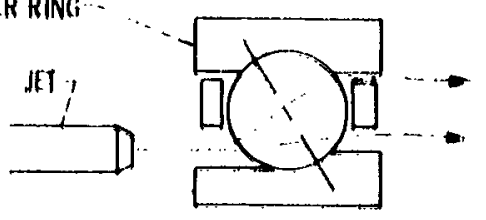

INNER RING

OUTER RING

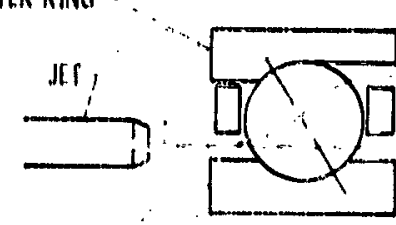

INNER RING

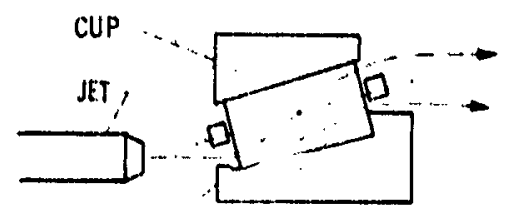

CONE -

Flgure 2. - Placemenl of jats for ball bearings wlth relleved rings and tapered-roller bearings.

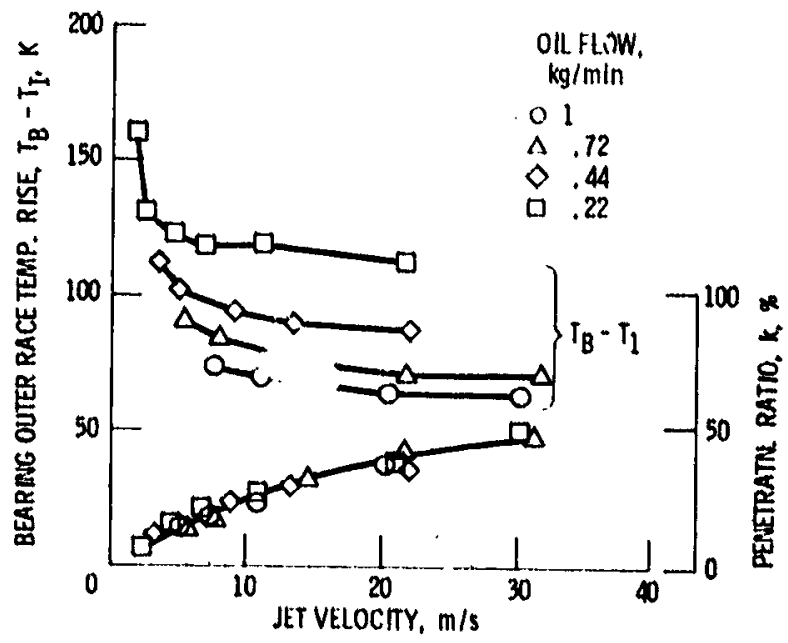

Flqure 3. - Bearing ouler race temperature rise and penetration ratio versus jet velocity. ITest bearing, 6206 louter race-riding cagel; shaft speed, 60000 $\mathrm{rpm}_{1}$ thrust load, $50 \mathrm{~kg}_{i}$ inlet oll temperature, $T_{I}$ $303 \mathrm{~K}$; from 1151.$)$ 


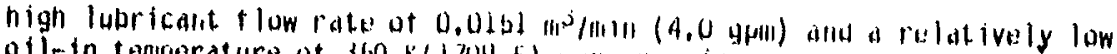
ofl-in temperature of $360 \mathrm{~K}\left(170^{\circ} \mathrm{F}\right)$ were requirea.

\section{UNDLRR-RACE LUHRICATIUN}

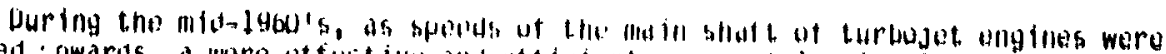

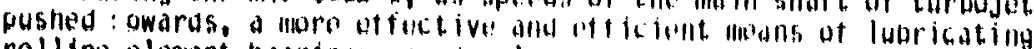

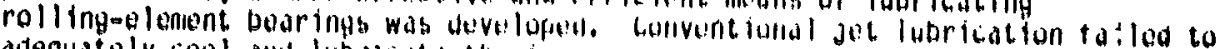

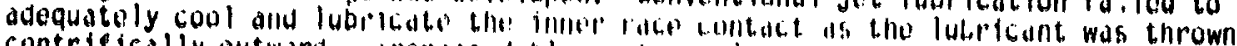
contrifically outward. Increased t luw rate:s billy added to hedt genteration from

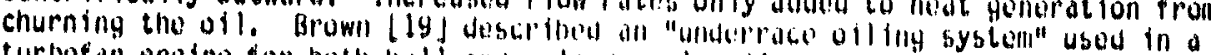

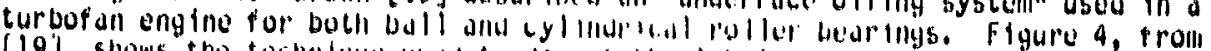

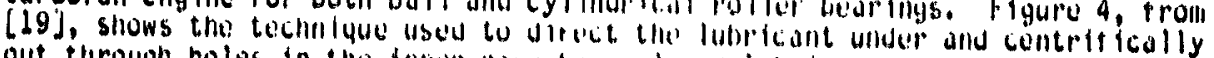

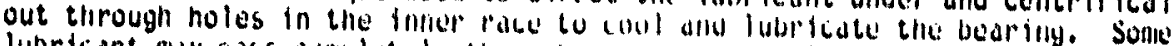
lubrtiant mas pass completuly through untere the bedrting tor coulling only as shown in Fig. 4(a). Althougli not shown lil the tigure, sullie ravial holos mas be used to supply lubricant to the culfu' riding lands.

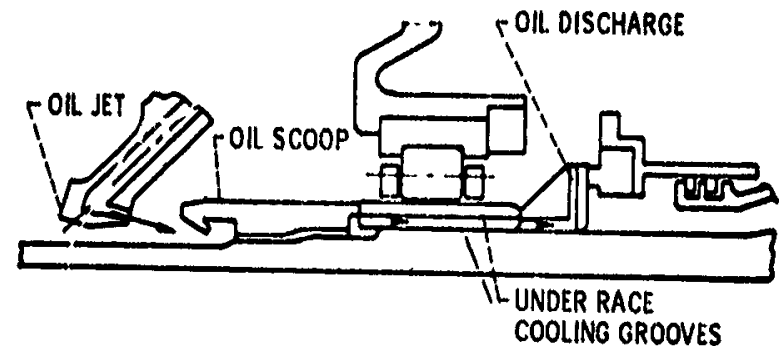

(a) CYLINDRICAL ROLLER BEARING.

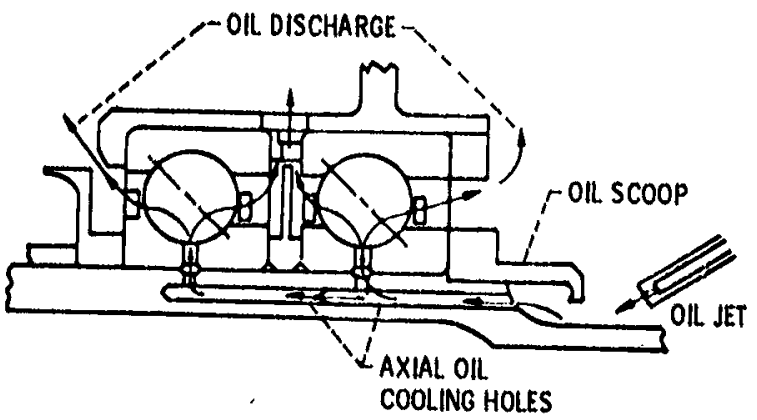

(b) BALL THRUST BEARING.

Flgure 4 - Underrace olling system for main shaft bearings on turbofan engine. (From [19].)

This lubricating technique has been thoroughly tested for large bore ball and roller bearings up to 3 million un. Results of these tests have been published by Holmes [20] with 12b-min- $\left(4.4212^{2}-\right.$ in,-) bore ball bearings, signer, et al. [21] with 120-rim- $(4,2244-11,-)$ bore ball bearinys, Browil, et al. [22] with 124-nni- $(4.881 y-\{11 .-)$ bore cylindrical roller bearinys, and sclluller [23] with 118-nm- (4.6457-in.-) bure cylindrical roller bearings. An cxample of the effect iveness of under-race lubrication alla cooling is shown th Fig. b from [17]. Under-race lubricated ball bearillys ran stynificantly cooler than thentical bearings run with jet lubrication. Beyolnd $10 \% 00$ ruifi (2 infliton UN), while that with jet lubrication incredsed librication increased only nonithally while that with jet lubrication increased at all accelerated rate. Only at "educed load comld the jet lubricated bearillys be run at 2.6 milition un. 


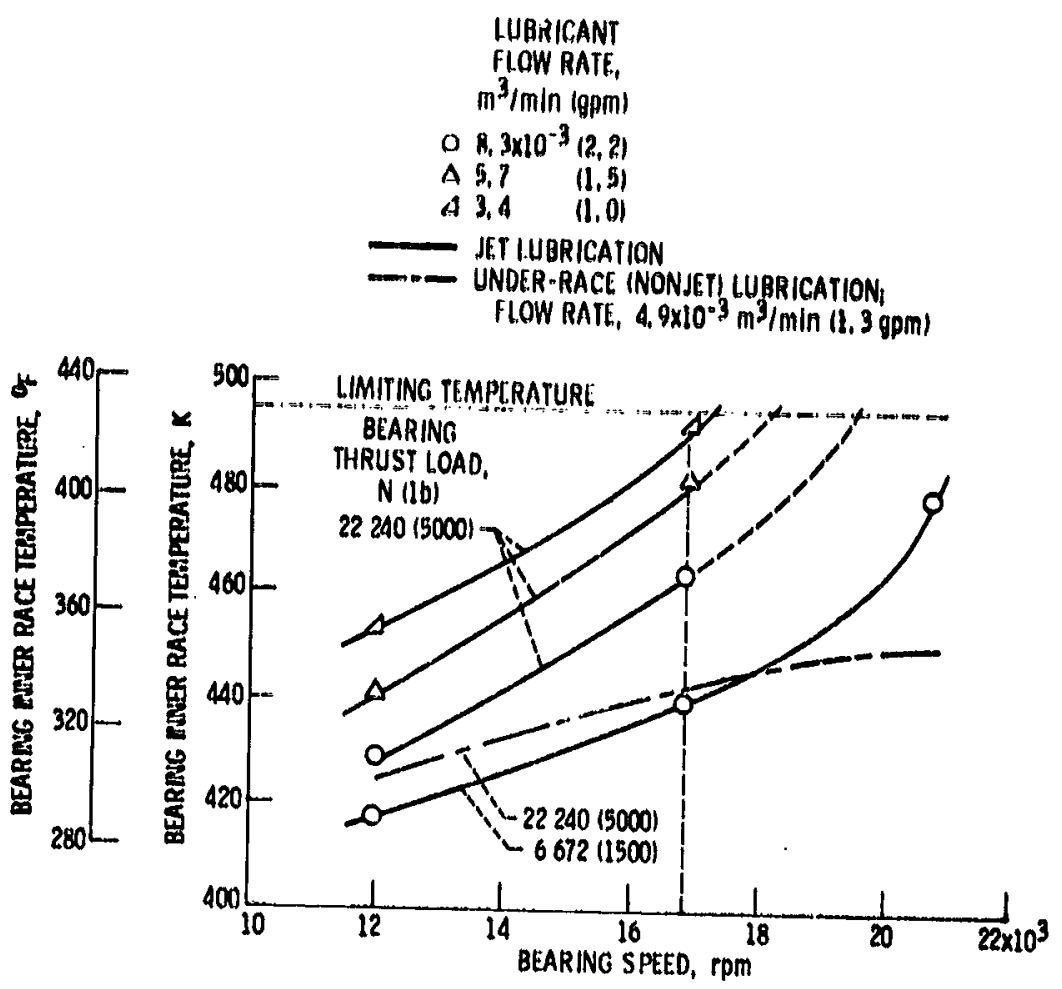

Figure 5. - Effectlveness of under-race lubrication with $120 \mathrm{~mm}$-bore angular contact ball bearings. (oll-In temperature, $394 \mathrm{~K}\left(250^{\circ} \mathrm{F}\right.$; from $\left.[17)^{\prime}\right)$

Under-race lubrication was successtully used under a variety of load conditions up to 3 million on [17 and 21$]$.

Applying under-race lubrication to snlall bore bearings ( $<40-\mathrm{mm}$ bore) is more difficult because of limited space avallable for grooves and radial holes. and means to get the lubricant under the race. Fur a given UN value, centrifugal effects are nore severe with silall bearings since certrifugal forces vary with UN². Heat generated per unit of surtace area is also much higher, and heat relloval is more difficult in sillaller bearings.

Although it was previously shown that operations up to 3 million on can be successfully achfeved with sillall bore bearings with jet lubrication, sone

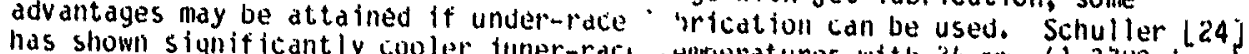
has shown significantly cooler finer-rac cemperatures with $35-n m-\left(1.3780-1 n_{-}-\right)$ bore ball bearings with under-race lubrication. As shown in Fig. 6, from [24], the effect is yreater at higher speeds up to 72000 rom $(2.5$ milition ON).

Tapered roller bearings have been restricted to lower speed applications relative to ball and cyllindrical roller bearings. The speed limitation is pritiartly due to the cune-rib/roller-end contact which requires very careful lubrication and couling consfuaration at higher speeds. The speed of tapered-roller bearings is limited to that which results in a UN value of $36 \mathrm{~m} / \mathrm{sec}(7000 \mathrm{ft} / \mathrm{min}$ ) destgning this cone-rib/rolle spectal attention is given to lubricating and effects starve this critical contact of lubricat. At higher speeds, centrifugal

In the late lyou's, tubricant.

tapered-roller be 1900 's, the technique of undararace lubrication was applied to cone-rib/roller-aring, that is, to lubricale and cool the critical

cone-rib/roller-end contact. As described in $[25]$, 88.9mem- $(3.5-1 \mathrm{n} .-)$ bore inillion uN with cones were run under comblned radial and thrust loads to 1.42 lubrication in tapered-roller bearings). 


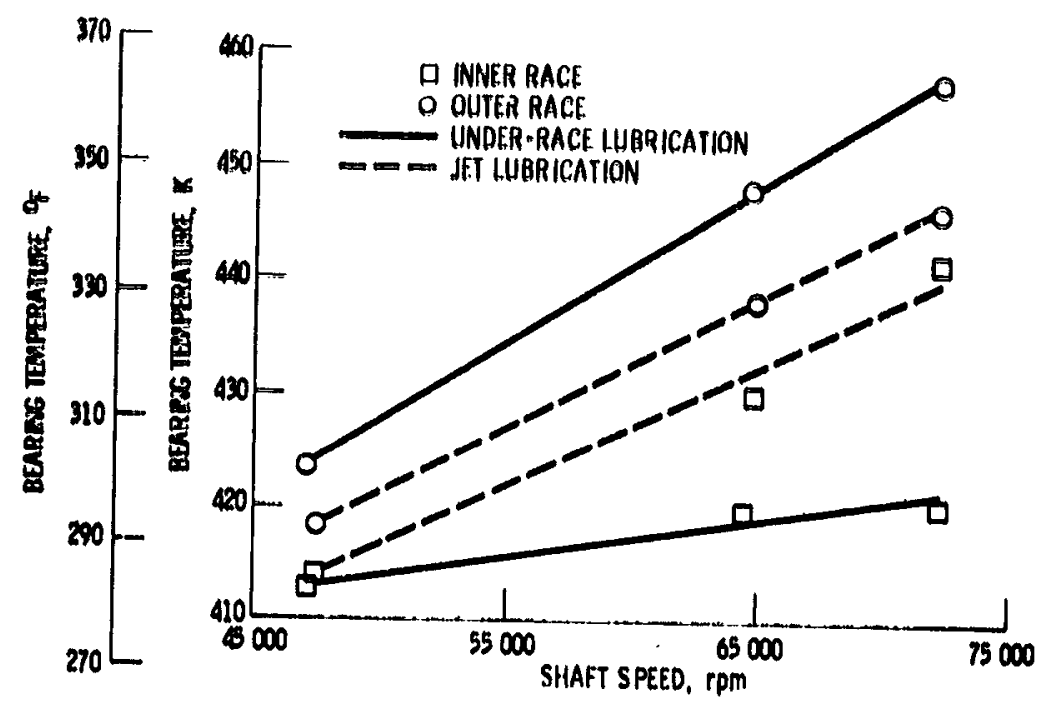

Figure 6. - Effecl of under-race lubrication with $35-\mathrm{mm}$ bore angular contact ball bearings. (Total oll flow rato, $1318 \mathrm{~cm}^{3} / \mathrm{min} 10.348 \mathrm{gpm} / \mathrm{h}$ oll-in temperature, $394 \mathrm{~K}\left(250^{\circ} \mathrm{F}\right)$ from $(241$.

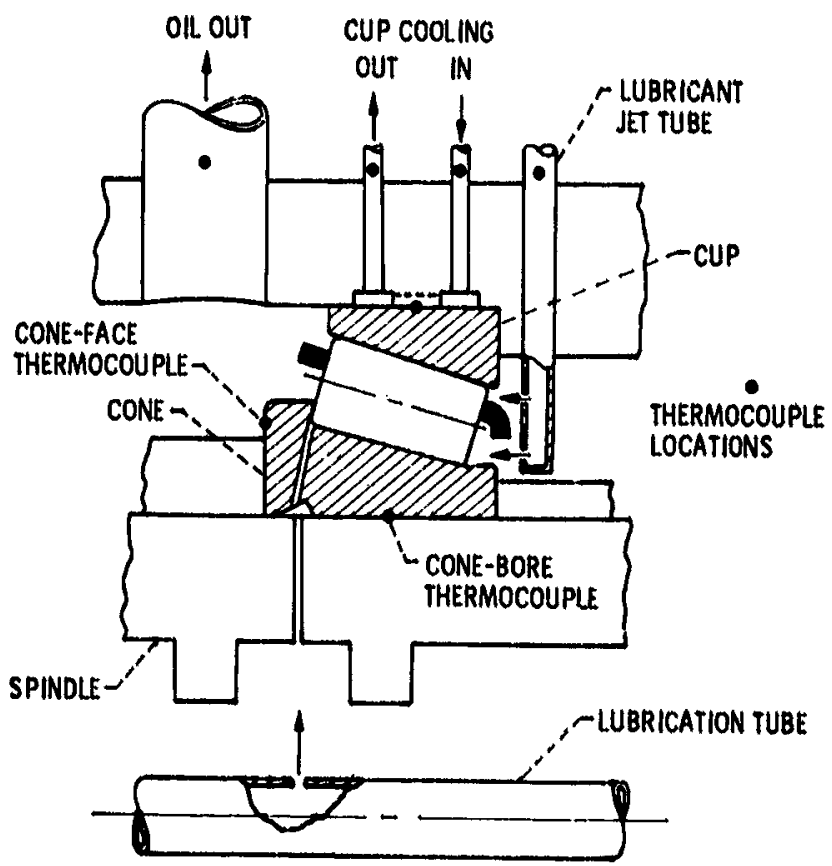

Figure 7. - Tapered-roller bearing with cone-rib and jet lubrication. (From [18I.) 


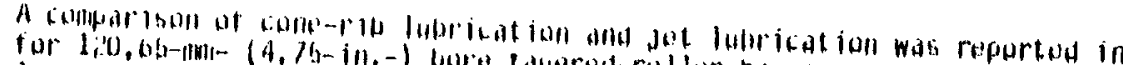

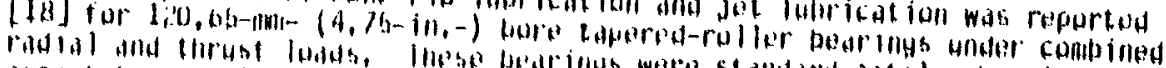

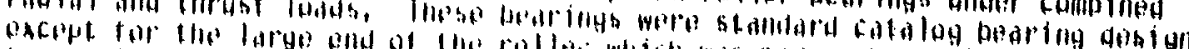

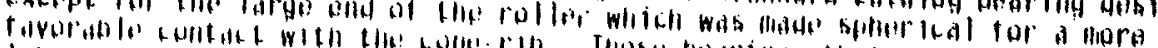

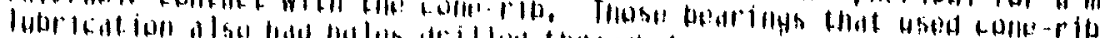

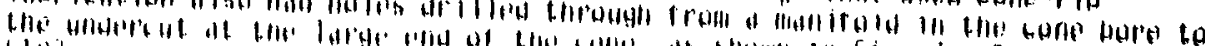

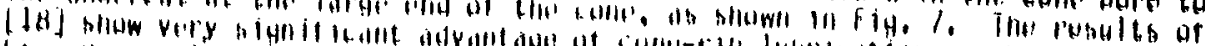

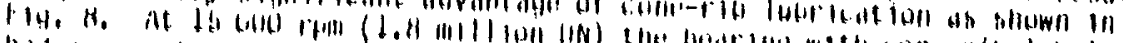

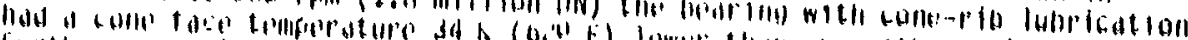

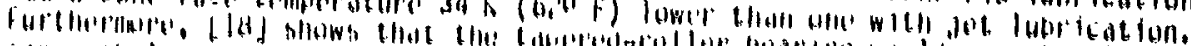

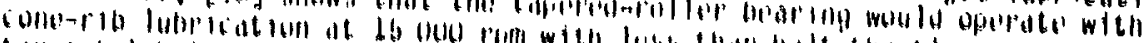

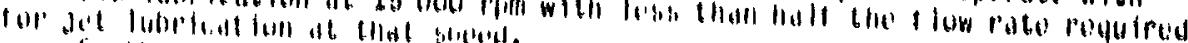

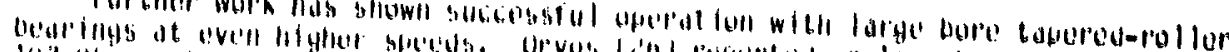

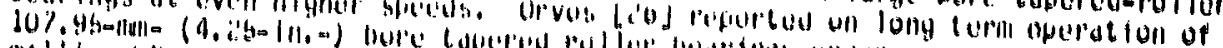

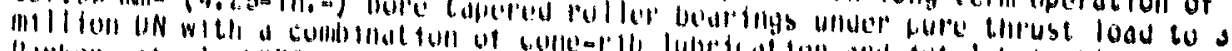

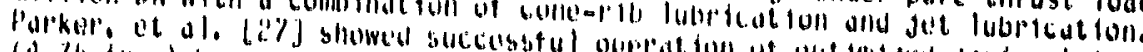

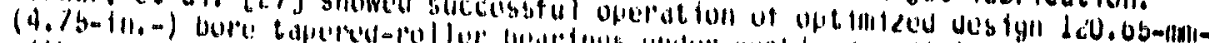

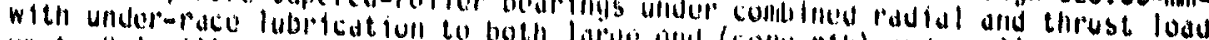
up to 2.4 mill ton $0 \mathrm{~N}$.

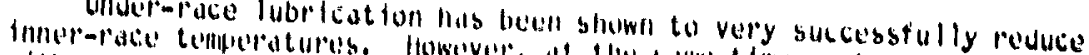

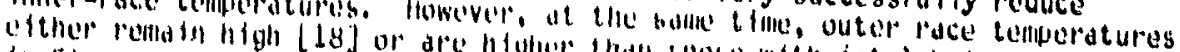

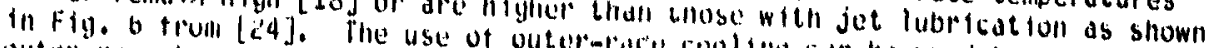
outer-arace temperature to leve is ater-lace cooling can be used lo roduce the would turther add to to thevels at or hear the finer-race cemperature. The and avoid large difterent fals in bearing hey of under-race lubricated bearings filternal clearallce.

The effect of tapered-roller beartites, see couling for cun cooling in the case of outer-surface temperature is dec. 7 ) is shown l.1 table 1 from li27j. The cus

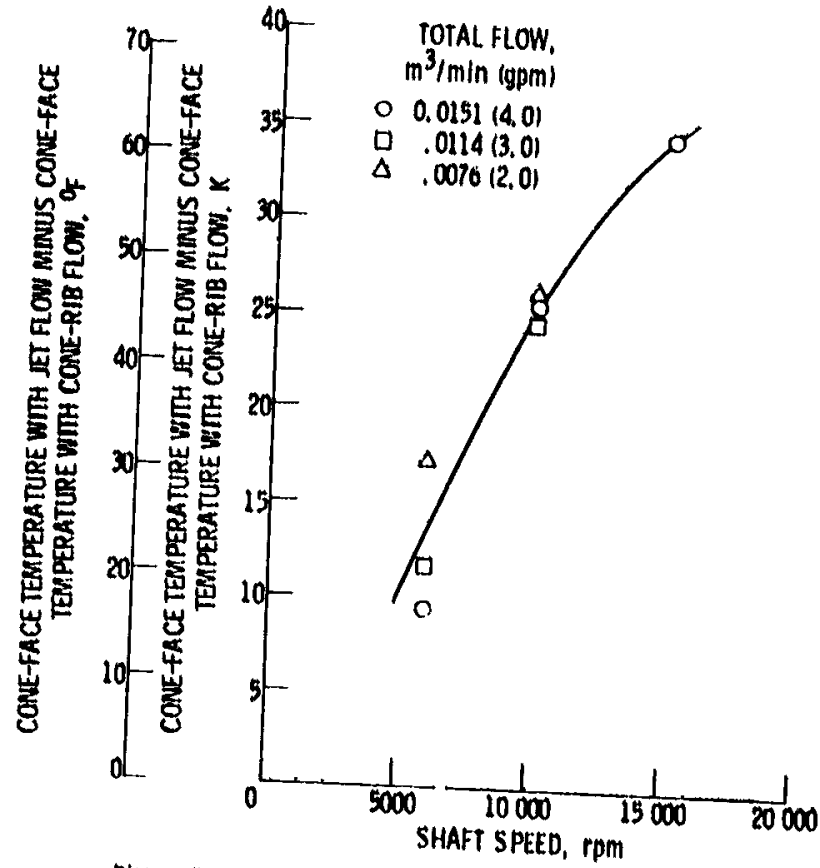

Figure \& - Advantage of cone-rib lubrication over jet lubricathon with 4.75-inch bore tapered-roller bearings. (oll-in temperature, $350 \mathrm{~K}\left(170^{\circ} \mathrm{Fi}\right.$, from 1181 . . 
TABLE 1. - EFFECT OF CUP COOLING ON TAPERED-ROLLER

\section{BFARING TEMPERATURES}

(Shaft speod, 18 bo0 rpmi ofl- in temperature, $364 \mathrm{~K}$ (1960 F) t total plaw rito withaut cup cooling, $0,011 \mathrm{~s} \mathrm{~m}^{3} / \mathrm{min}(3,0 \mathrm{gpm})$; from $\left.(? 7),\right)$

\begin{tabular}{|c|c|c|c|c|c|}
\hline \multirow{2}{*}{$\begin{array}{l}\text { cup coolling } \\
\text { f gow rato } \\
\mathrm{m}^{3} / \mathrm{min} \text { (gpm) }\end{array}$} & \multicolumn{5}{|c|}{ Tomperature, K (OF) } \\
\hline & $\begin{array}{l}\text { Cono } \\
\text { faco }\end{array}$ & $\begin{array}{l}\text { Cono } \\
\text { born }\end{array}$ & $\begin{array}{l}\text { Cup outor } \\
\text { surfaco }\end{array}$ & 01 logut & $\begin{array}{c}\text { Cup cool ing } \\
\text { ofl=out }\end{array}$ \\
\hline 0 & $\begin{array}{c}389 \\
(240)\end{array}$ & $\begin{array}{c}423 \\
(302)\end{array}$ & $\begin{array}{c}438 \\
(329)\end{array}$ & $\begin{array}{l}426 \\
(307)\end{array}$ & manc \\
\hline $0.0038(1.0)$ & $\begin{array}{r}391 \\
(245) \\
\end{array}$ & $\begin{array}{r}424 \\
(303) \\
\end{array}$ & $\begin{array}{r}424 \\
(304) \\
\end{array}$ & $\begin{array}{c}426 \\
(308)\end{array}$ & $\begin{array}{c}386 \\
(235)\end{array}$ \\
\hline
\end{tabular}

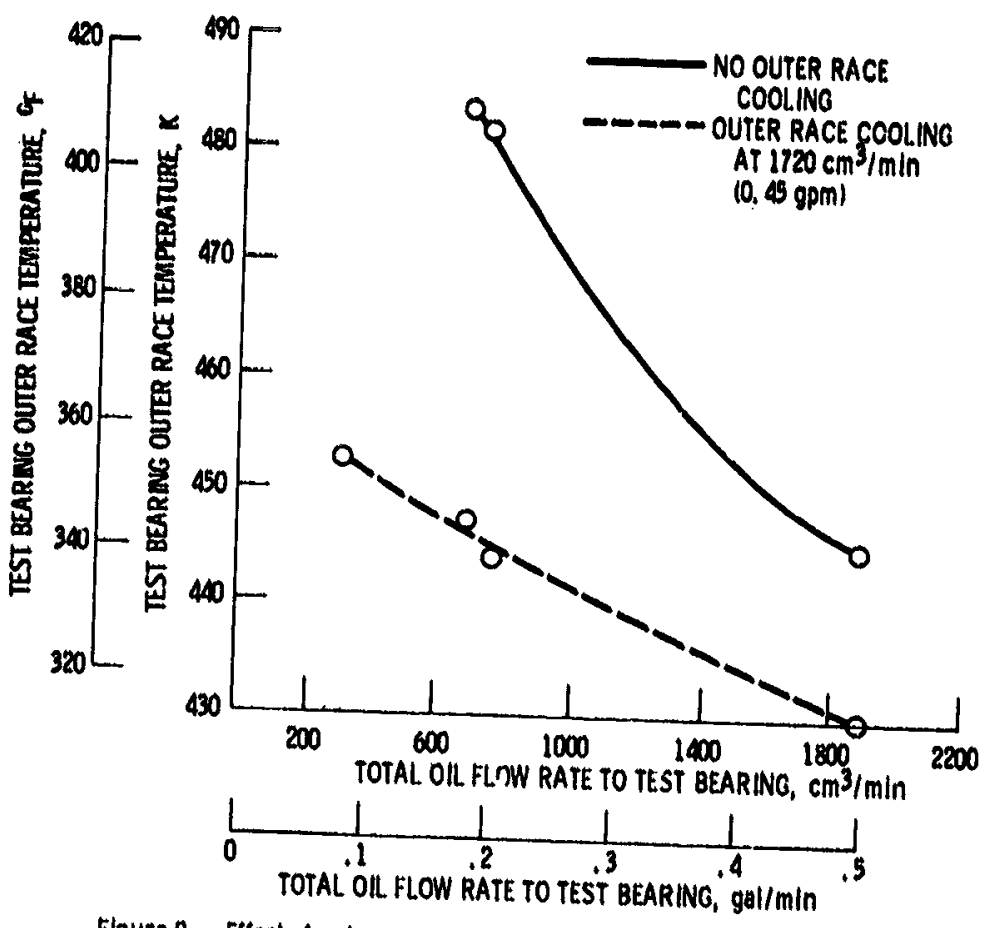

Figure \%. - Elfect of outer race cooling on outer race temperature of $35-\mathrm{mm}$ bore ball bearings at $72300 \mathrm{rpm}$, coil--in temperature, $394 \mathrm{~K} 1250^{\circ} \mathrm{F} / \mathrm{from}(24) .1$

cooling. With the 35-mm- $(1.3780-111 .-)$ bore ball bearings of $124 \%$, outer-race Under-race lubrication has beermace temperatures as shown in - 19.4 . is currently being used with many airch ll developed for larger bo.et iearings and Because of the added difticulty of applat turbine engine midinshafe bearing. lubrication with small bore bearings has been thinime use under-race been demonstrated. It apears that has been minimal, but the benefits have higher speeds using cone-rib lubric ation ication of tapered roller bearings at has been primarily in laboratory test rigs. 


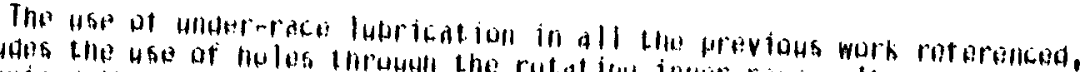

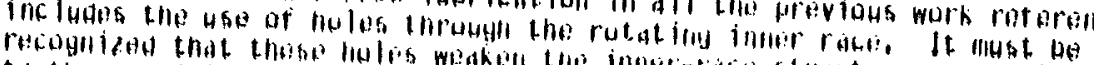

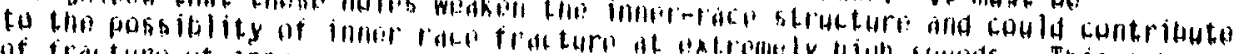

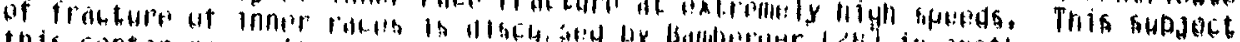

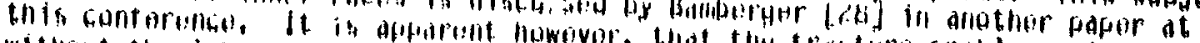

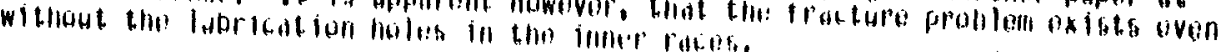

\section{SHLABH ONR IHATH LIBIKILATIUN}

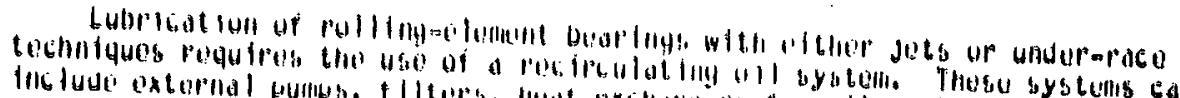

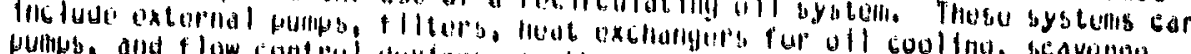

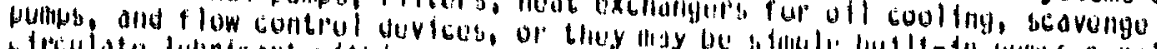

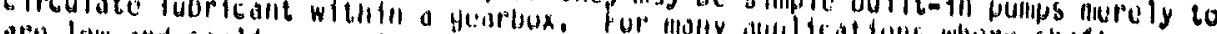

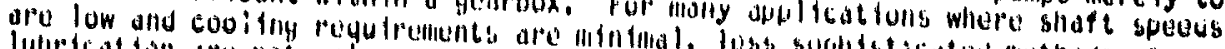

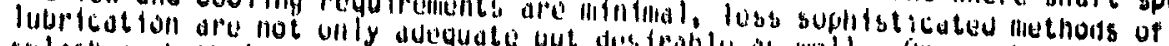
splasil or bath lubricat fon where papt destrable as well. Une such nethoo is immersed in lubricant. Thts nethod is genterdly fing or all adjacent component is hag law niatntonarice costs. It genord generdly lnexpens ive to incorporate ano rollable, since a filte, and generderlly requires little attuntion and is the system showlo be enclosed and weil sellill qualtity of lubricant is used. foretgn debris and dipt out of the systed sted. This is also necessary to keen through filters as it would in a circulating since the lubricant does not pass both lubrication is fairly conmon in thastertal temperature cundtions are not severe lindustrtal fidchinery where speed and technology has been developed or required tonsequently. little if any new

\section{WICK LUBP.ILATION}

A wick lubrication system is also relatively simple and inexpens ive to incorporate and maintain and is commonly used in many less severe operatirits conditions. This method uses a wick of felt or maste less severe operatiris reservoir to the bearing. 011 is transported or waste packing to link an oi material. The systen can be designed to use by capfllary action in the wick circulation allows sone filtering of the use lubricant recirculistion. This Sune more sophisticatering of the lutricart.

or proposed are in air turbine arives ato inere wick lubrication is being used applications, speeds are generallyes alis in energy storage flywheels. In both low to moderate. Thus, cooling? the bearings with jetiental temperature is lubrication is nint required.

The flywhee i application.

is, flywheels are generally run in a moderated environmental condition: that Wick lubricated bearings promise to be desire vacuum to reduce windage losses. relative simplicity and low torque losses.

Figure 10 depicts the wick lubrication of a ball bearing to support an

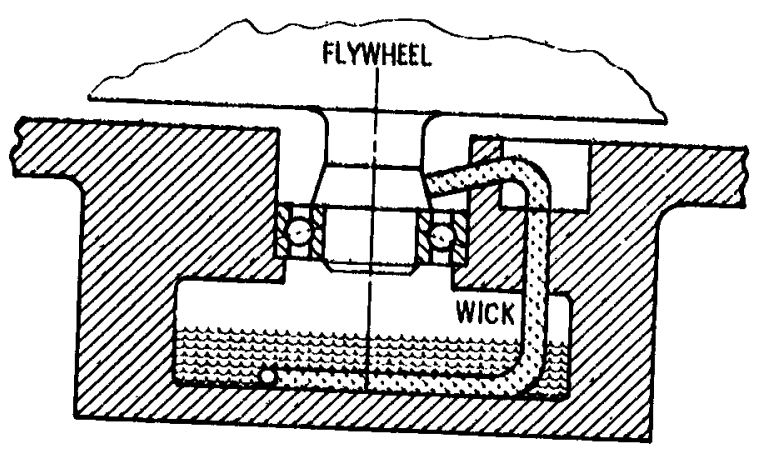

Figure 10. - Wick lubrication of ball bearing for energy storage flywhed. 
energy storase flywhel presently undergoing testing at the author's laboratory. The wool folt wick transports ofl from tha resorvoir to a tapared sleove above the bearing. The oil is centrifugally fod to the baaring, is circulated throwgh the bearing and returned by gravity Dack to the reservoir. Unoublished tests havo shown stable dind successful oporation with this system with $25-\mathrm{mm}$ bore ball bearings to 20000 rumil in a vacuun of $0.1 \mathrm{~mm} \mathrm{Hg}$.

\section{AIR-OIL. MIST LUBRILATION}

Anothor commonly used lubricatiun mothod for roliing-alement bearings is air-cill mist or derosol lubricatioll. This method uses a suspension of fine ofl particles in air as a fog or mist to trallsport ofl to the bearing. The foy is then reclassiffed or condensod at the bearing so that the ofl particles will wet the bearing surfaces. Reclassification is extreniely important, since the small ofl particles in the fog do not redully wet boaring surfaces. The reclassiffor generally is a nozzle that accelerates the fog, forming larger ofl particles that more readily wet bearing surtaces.

Air-oll nitst lubrication is non-recirculating; the ofl is passed through the bearing once and then discarjed. Very low ofl flow rates are suffictent for lubrication of rolling-elentent bearings exclusive of the cooling function. This type lubrication has been used in industrial machinery for over 50 years. It is used very effectively in high-speed, high-preciston machine tool spindles. A recent application of an a 1 -oil mist lubrication system is in an emergency lubrication systent for ma inshaft bearings in a U.S. Army helicopter turbine engine. An emergency lubrication system was required to allow safe engine operation for up to 30 minutes in the event that the primary lubrication system (recirculating jet) suffered severe ballist ic damage.

An experimental progran which verifies the feasibility of this approach was reported by Rosenlieb in [29]. It denionstrated that an a ir-0il mist system a long with auxillary cooling air could provide satisfactory short term operation of a $46-\mathrm{mm}$ bore angular-contact ball bearing to speeds up to $3.0 \mathrm{~m} f 1$ lition ON. Successful tests up to 100 hour duration were performed at 2.0 million oN with a mist oll flow rate of $284 \mathrm{~cm}^{3} / \mathrm{hr}(16.7 \mathrm{in.} / \mathrm{hr})$, a cooling air flow rate of $0.337 \mathrm{scmm}(11.9 \mathrm{scfm})$ and a bearing temperature of $472 \mathrm{~K}(3900 \mathrm{~F})$. Thts 011 flow rate to the bearing is at least two orders of magnitude less chan would be required in a jet lubrication systen for these conditions. However, over a 100

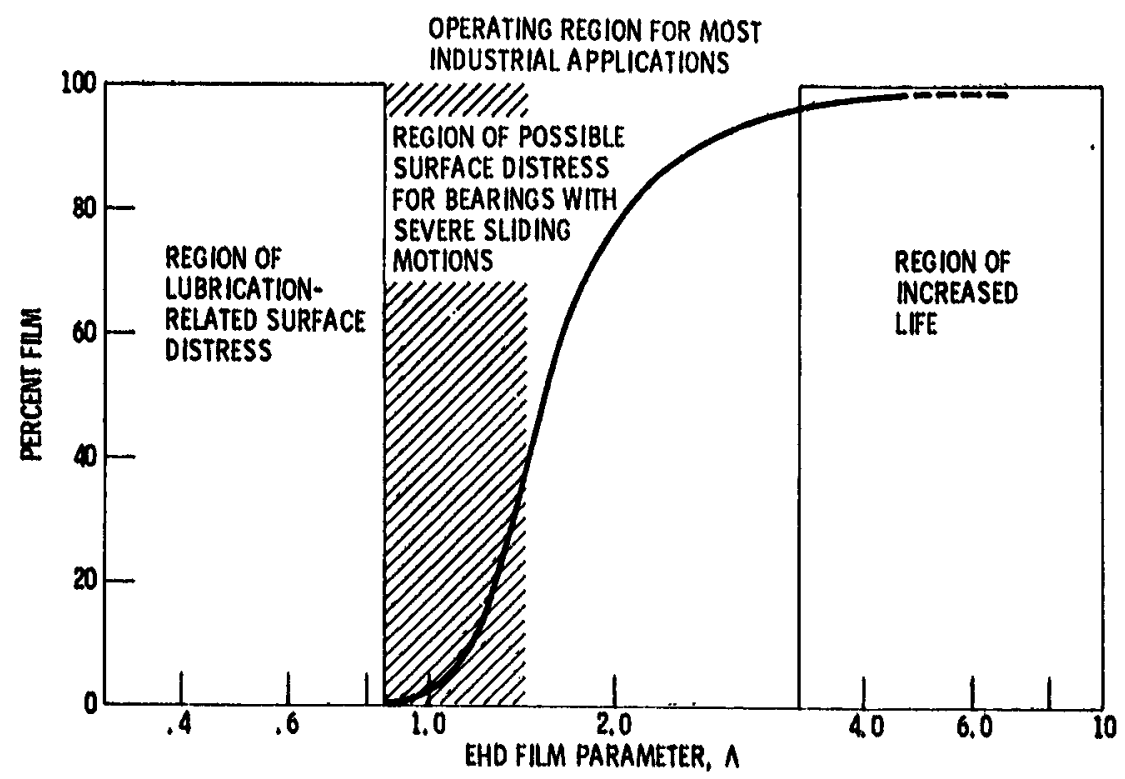

Flgure 11. - Percent fllm as a function of EHD fllm parameter. (From (31).) 


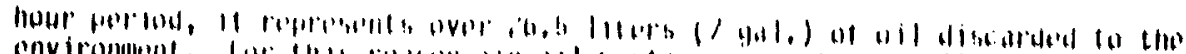

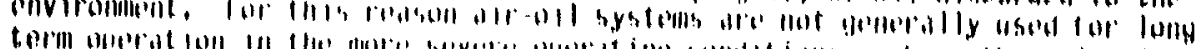

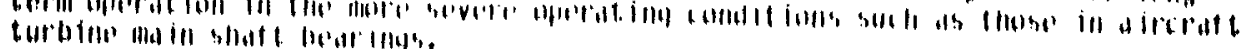

tho al t law

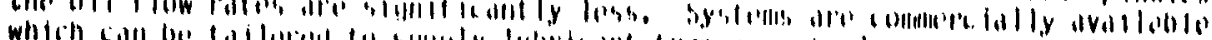

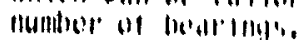

\section{IUIIRILAIIUN RIIAIII SIIRI MU! I ALIURI MUUIS}

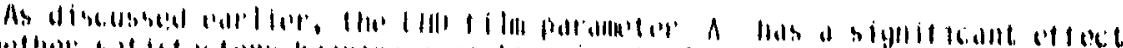

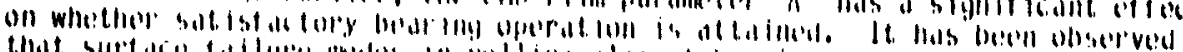

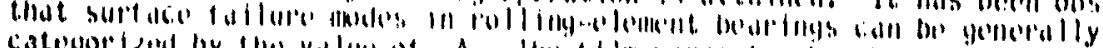

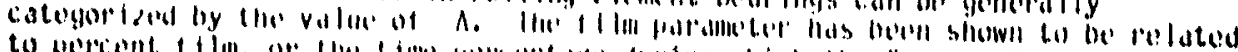

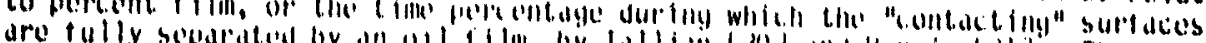

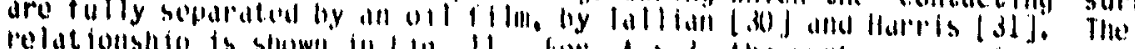

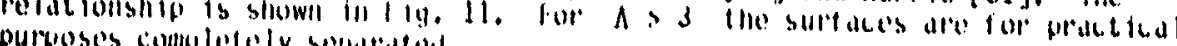

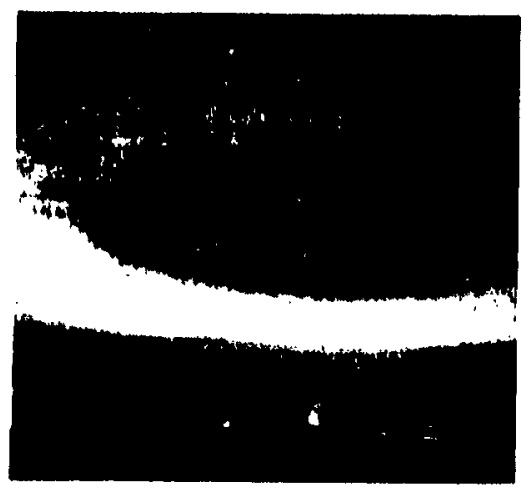

(a) NORMAI RAC: APPHARANCH AI II.R BE INS: RIIN WIIH PIIII IIASIOUIYDROI)'NAMIC L.UBRICAILIN.

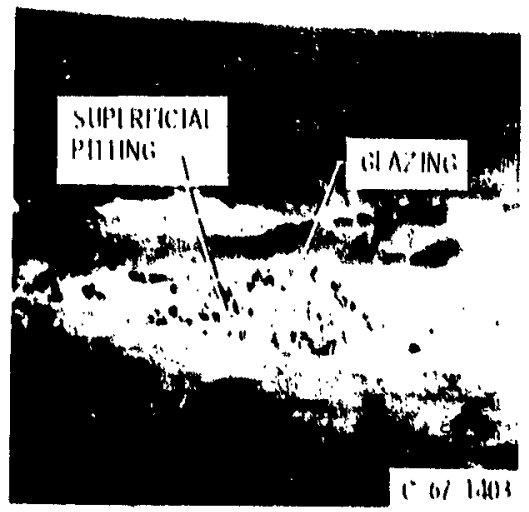

(c) RACI I'PUIARANCI AIIIR GI A: INC: AND SIIP'IRHIIIAI PIIIINLi.

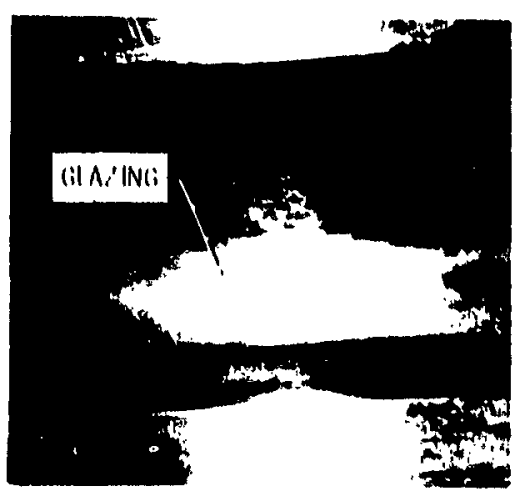

(b) RAC' API'IARANCE AFIER GLAZINO.

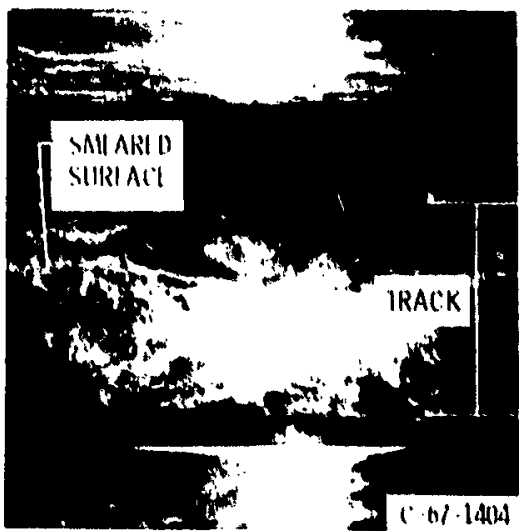

(II) RAC!I APP'IARANC:I AIIIR SMLARING.

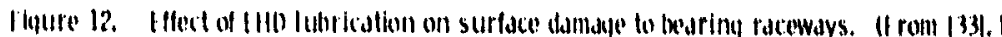




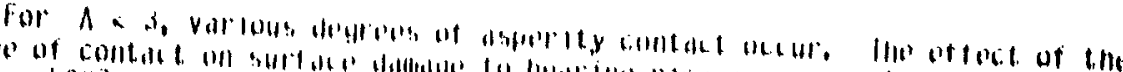

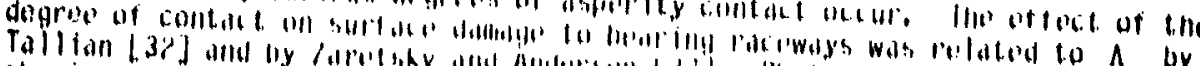

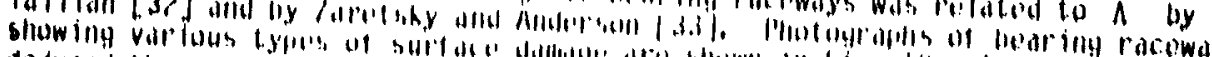

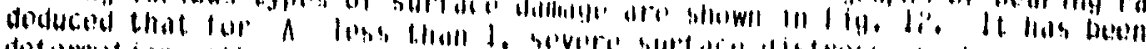

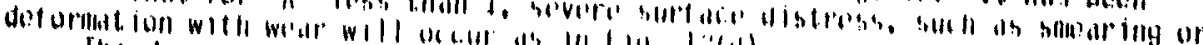

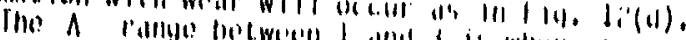

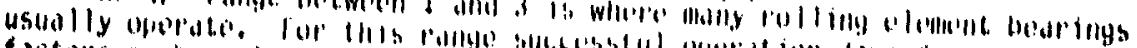

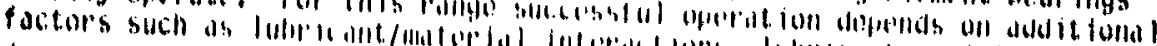

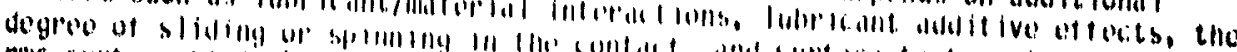

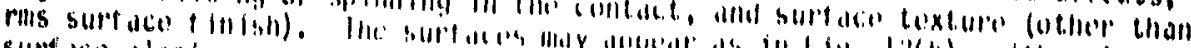

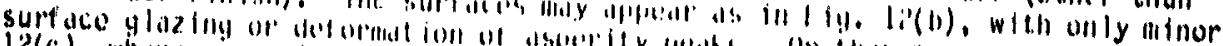

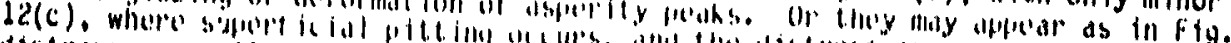

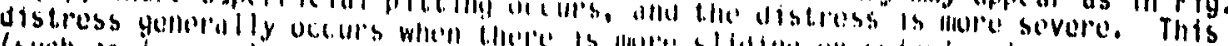

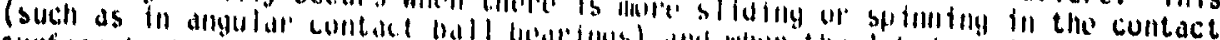

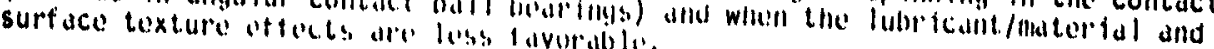
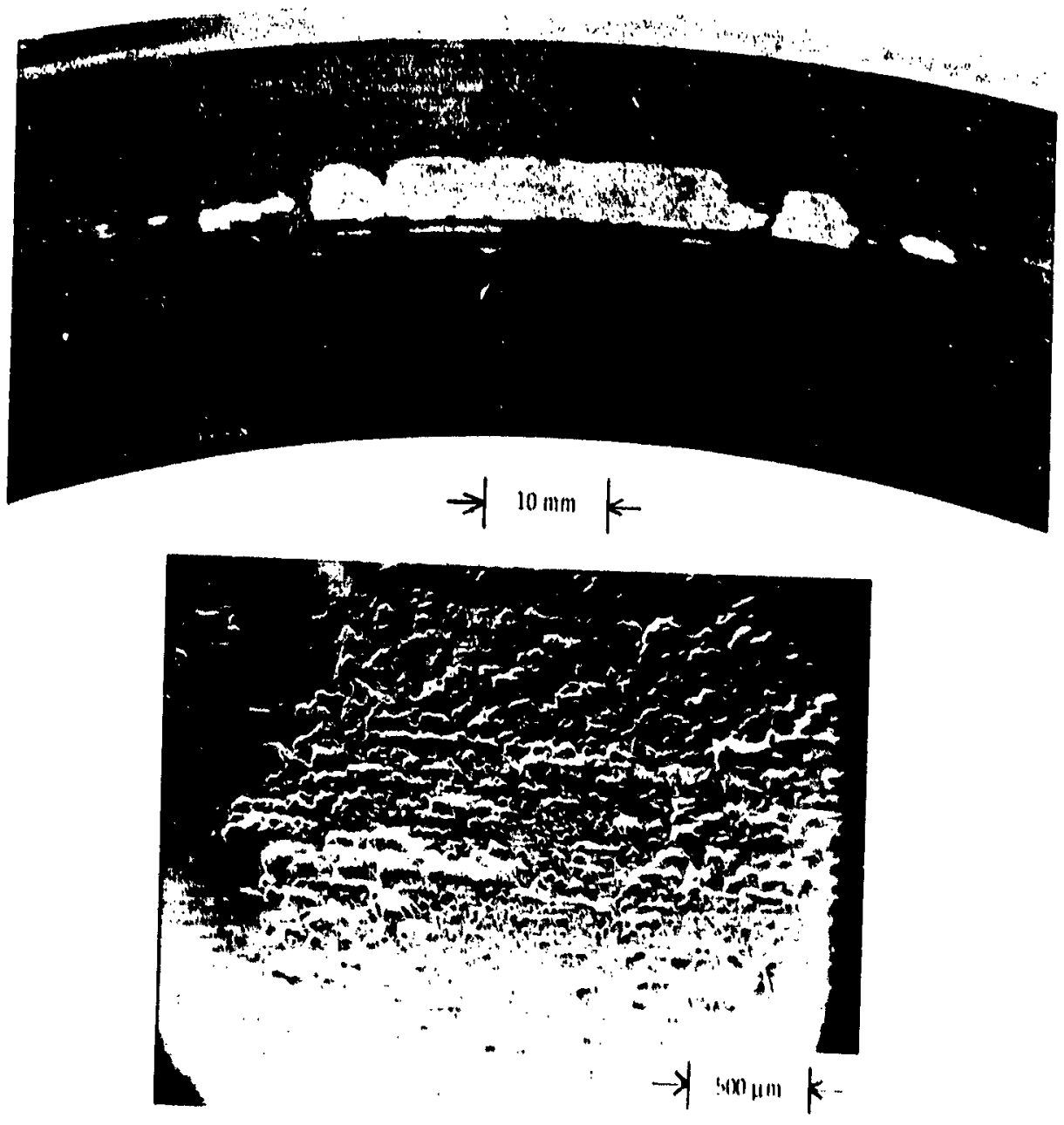

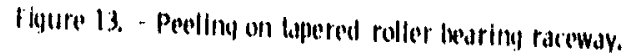




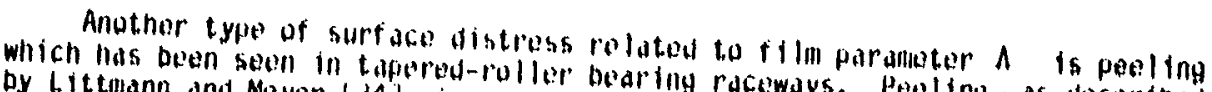
by hittmann and Mayor [3A], is a very bedrling raceways. Peoling. as described less than $0.013 \mathrm{mon}(0.0006$ ill.). Fery shallow arod, unitorm in depth usually tapered-roller bearting with periting. It was shewn ap raceway surfaco of a could bo oliminated hy improving the $A$ value show that this nodo of distress author's laboratory). By improving surt aco fue (unpublished tosts at the tomperaturo to incroaso $\Lambda$. the pooling distions alld lowering operating To preclude surf dio distrubseling distross was avolded.

falluro, $A$ values loss than 3 should possible carly rollfirg-olenent bearing attained, the appearance of the rdeciway surotaces. When this condition is Fig. 12(a) whero origind grinding mork surtace slould be simflar to that of

\section{LUBRICATION EFPLLLTS UN FATIGUE LIFE}

The EHU film parameler $\Lambda$ has added significance with respect to the fotfgue life of rolling-elonient bearinys. Tall tan [32] related $\Lambda$ to bearing values less than 1. This implies that even thougt the curve extends to surfaces distress could occur, cont thued unerat ton $\Lambda$ is such that significant initiated spalling fatigue.

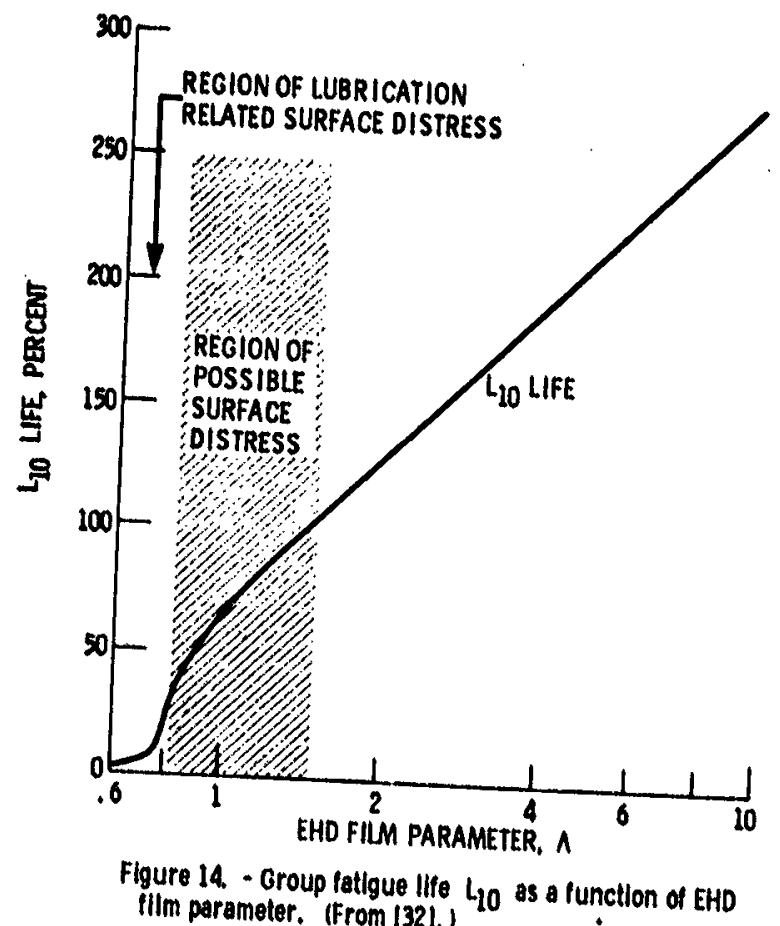

Skurka [3b] published results of tatigue tests with cylinarical roller [36] have reconmenge of $A$ values simflar to that of Fly. 14 . The roller and skurk 's $[5]$ d an average curve, Fig. 15, based on. 14. The authors of factor. To obtain ata. This curve call be used to deteruine thallians' [32] calculated afbat a bearing lite that is adjusted dor lube a lubrication The cffects of lug life is multiplied by this factor. Tall the crfects of lubrication on fat lyues life have oetor.

Tallian [3] who describes a nore sophisticated have been critically explored by et al. [38] is useffects allong other tactors. This wark includes asperity in data showing effects explaining sone of the scatter that $[37]$ and that of $[$ iu,  


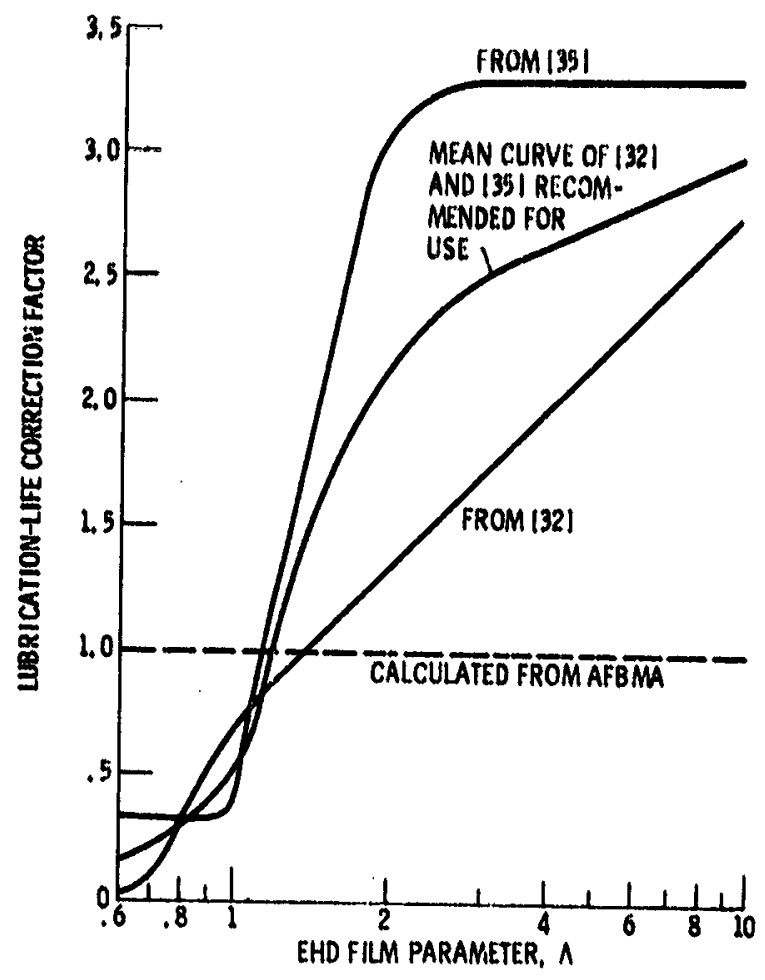

Figure 15. - Lubrication-life correction factor as a function of lambda. (From 136 ).)

Lffe correction factors for lubricant effects are now being used in sophisticated computer prograns for andlys is of rolling-element bearing performance such as those of creceltus [39] and klechner [40]. In such programs, the lubricant 11 lim parameter is calculated, and a life correction factor is used in bearing life calculations. Further discussion of these

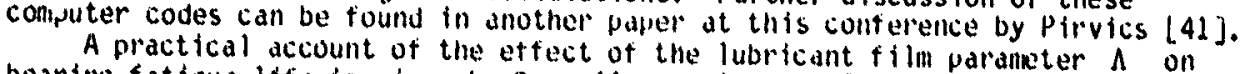
bearing fatigue life is given by Russell and clark [4:]. A group of aircraft turbine engthe ma in shaft ball bearings were tound to hive poor outer raceway surface finishes. The tailgue iffe determined from rig testing these bearings was found to be significantly less than the life of si llar bearings with proper surface finishes and considerably less than prodicted by methods of [30]. The bearings with poor outer raceway finishes had a calrulated $\Lambda$ value at the outer-race-ball contact of $0 . \%$. Acceptable fillishes on the outer raceway gave a calculated value of approxinlately 3 . The experitmental results showed two orders of magnitude life difference, whereds the eredicted life difterence was considerable less than one order of mannitude.

No other published data known to the author have shown such large life difference due to lubrication effects. It is possible that other factors entered tinto the lite reduction such as materiallabricant interactions and chemical effects. Ut to now, investlgators have concentrated un the phystial factors involved to explath the greater scatter in lite results at low $\Lambda$ invest Material/lubricant chenical interactions have not been adequately investfyated. From decades of boundary lubrication studies, it is apparent that chemical eftects must blay a signiffiant role where there is apprecidule asperity interaction. More work needs to be done in this ared. 
It is well rougnized that fatigue fallures which occur on rolling-olentent. contacts aro a consequence of competitive fallure nodos develop ing primarlly from of ther surtace or subsurfaco defects. Subsurface initiated fat lgue, that which originates slightily beluw the surface in a region of nigh shearing stress. is genorally tho mode of tallure for properly designed, wall lubricated, and we 11 ma intained rolling-clemont bearings. Surface initiated fatigue, of ton originating at the tralling ouge of a localized surface defect, is the most prevalent mode of fatiguc fallure in machinery whore strict lubricant. cleanliness and/or sufficient EHD fllm thickness aro difficult to maintain. The presence of cuntaminants in rolling-element systems will not only increase the likelinood of surface initlated fatigue but can lead to a slgnificont degree of component surface distress. In [43], experiments performed on taperud-roller bearings have shown that wear is proport tonal to the amount of contamination in the lubricant, and that the wear rate generally increases as the contaminant particle size is increased. Furthermore, the wear process will cont inue as long as the contaminant particle size exceeds the EHD film separating the bearing surfaces. Since this film thickness is rarely greater than 3 microns ( 118 win,) for a rolling contact component, even extremely fine contaminant particles can cause some damage.

The research of [44] showed that an 80 to 90 percent reduction in ball bearing fatigue life could occur when contanitnant particles were cont inuousily fed into the recirculating lubrication system. Also, bali bearing life tests reported in [45] suggest that the use of an "ultraciean" lubrication system may improve bearing life several-fold over a conventional lubrication system.
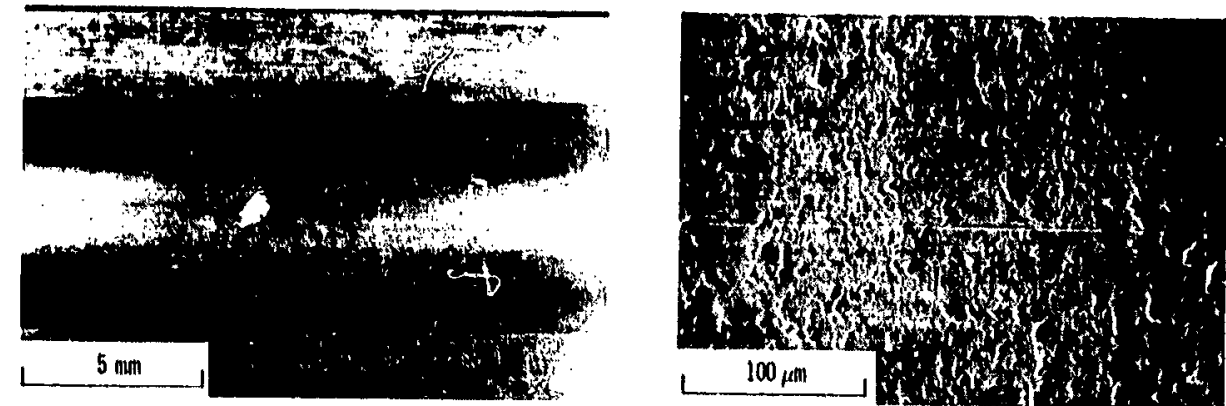

(a) TEST BEARING SUSPENDED AFTER 1172 hOUrS FROM 3-micron-ABSOLUTE FILTER TESTS WITH CONTAMINATED LUBRICANT ITEST SERIES III.
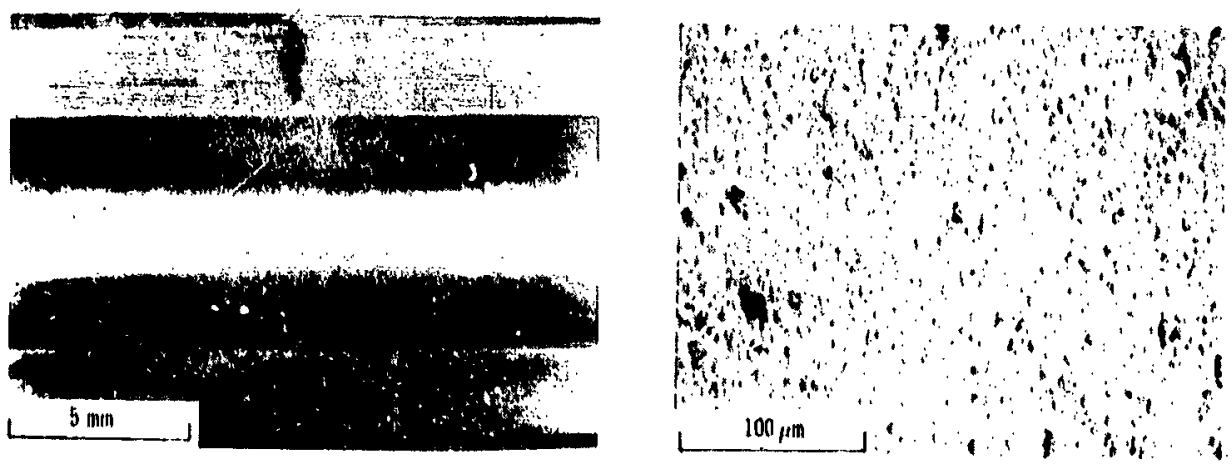

(b) TEST BEARING SUSPENDED AFTLR 987 hourS FROM 30-micron-ABSOL UTE FILTER TESTS WITH CONTAMINATED LUBRICANT ITEST SERIES IIII.

Flgure 16. - Macro- and SEM-photographs of inner races of 65 - $\mathrm{mm}$ bore ball bearings showing progressive surface damage of running track with codrser lilter s|ze. (From $|46|, 1$ 

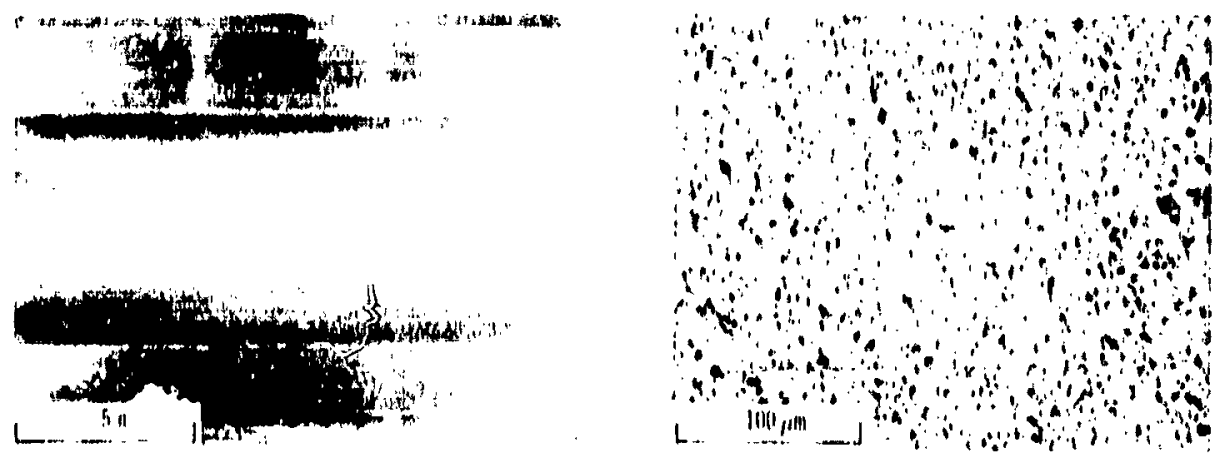

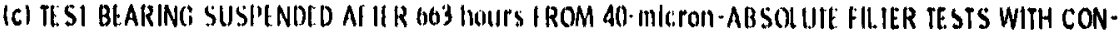
TAMINATED I.UIRIICAN! IIESI SI RIIS IVI.
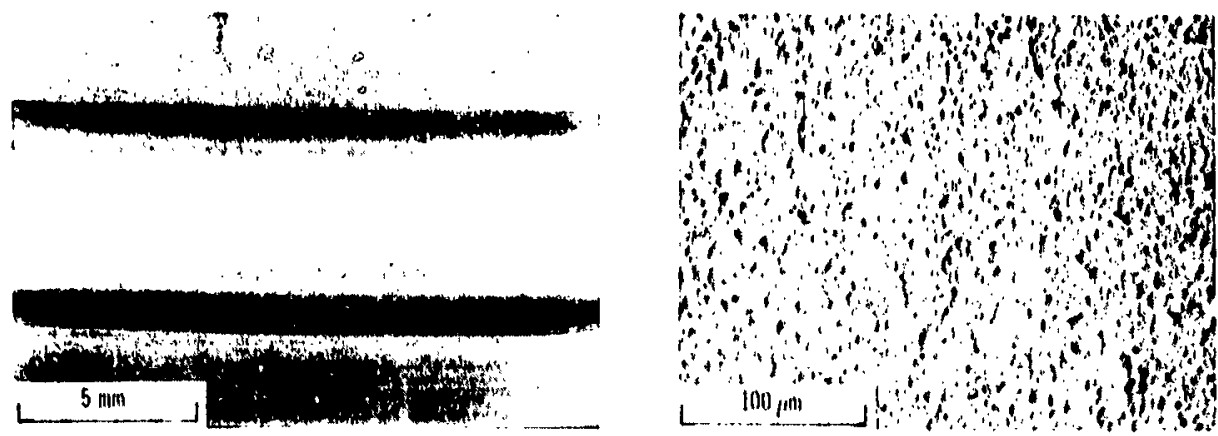

(d) TEST BEARING SUSPENDED AFTER A4Y hourS FROM 105 -micron-ABSOLUTE FILTER TESTS WITH CONTAMINATED LUBRICANI IITST STRILS VI.

Figure 16 . - Concluded.

Loewenthal and Moyer $\lfloor 46\rfloor$ reported that finer filtration improved bearing fatigue life and decreased wear of bearing components run in a system containing lubricant contaminated with carbon, stliceous and metallic particles. The photographs in $\mathrm{Fig} .16$ show inner raceways of the 6b-mm- $\left(2.5590-i \mathrm{n}_{0}-\right)$ bore ball bearings run in these tests and illustrate the progressive increase in surface distress and wear with coarser tilter size. This is reflected by an increase in the intensity and width of the wear track coupled with the increasing absence of grinding marks. Although bearing fatigue life was simflar for the 3 micron and 30 micron filter tests, the use of filters coarser than 30 microns reduced bearing fatigue life as shown in Table 2.

There has been a reluctance to use fine fllters because of the concern that fine lubricant filtration would not sufficiently improve conponent reliability to justify the possible increase in system cost, weight, and complexity. In addition it is presumed that fine filters will clog more quickly, have a higher clean pressure drop, and generally require more maintenance than currently used filters. The study described by Lynch and Cooper [47] demonstrated that these presumptions are not diways correct. In this study, tests were performed on a 3-micron absolute ma in oil filter which replaced the original production 40-micron nominal (6b-micron absolute) filter for a hellcopter yas turbine engine lubrication system. The new t fiter elements provided a much cleaner lubricant with less component wear, while greatly extending the time between filter removals for clogging and oil changes. This was accomplished with a modest increase in filter size and weight and with a new filter clean pressure drop nearly the same as the original production unit. The turboshaft engines which power advanced lielicopters such as the Army's UTTAS and AAH now use 3-micron absolute filtration in their lubrication systems. 


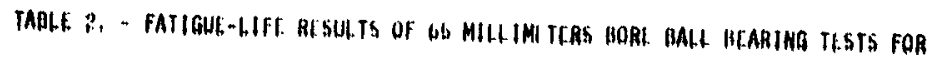
VARIOUS LEVCLIS OF IIITRATION IN A CONTAMIMATED LURRICANT

(Rodial load, Abnu $N(10,30$ lof); apend, 15000 romb tomperatura, 947

\begin{tabular}{|c|c|c|c|c|c|c|c|}
\hline \multirow{3}{*}{$\begin{array}{l}\text { Tant } \\
\text { corianas }\end{array}$} & \multirow{3}{*}{$\begin{array}{l}\text { Foit } \\
\text { Plitur } \\
\text { absoluto } \\
\text { ratine. } \\
\text { H }\end{array}$} & \multicolumn{2}{|c|}{ liaporimental hourt } & \multirow{3}{*}{$\begin{array}{l}\text { Wolbull } \\
\text { nlapon }\end{array}$} & \multirow{3}{*}{ Fallure } & \multirow{2}{*}{\multicolumn{2}{|c|}{$\begin{array}{c}\text { Conf idenco number, } \mathrm{c} \\
\text { percont }\end{array}$}} \\
\hline & & \multirow{2}{*}{$\begin{array}{l}\text { lorpercont } \\
\text { lifo. blo }\end{array}$} & \multirow{2}{*}{$\begin{array}{l}\text { bonperecint } \\
\text { lifo, I so }\end{array}$} & & & & \\
\hline & & & & & & 10mpercont & bo-phrcent \\
\hline$\prod_{d v}^{i v}$ & $\begin{array}{r}49 \\
3 \\
30 \\
49 \\
106 \\
\end{array}$ & $\begin{array}{l}679 \\
606 \\
594 \\
367 \\
\cdots\end{array}$ & $\begin{array}{c}717 n \\
993 \\
851 \\
633 \\
\cdots\end{array}$ & $\begin{array}{l}1.64 \\
0.76 \\
b .12 \\
6.116 \\
\cdots\end{array}$ & $\begin{array}{l}9 \text { uut of } 32 \\
10 \text { out of } 16 \\
11 \text { out of if } \\
\text { bo out of } 32\end{array}$ & $\begin{array}{l}39 \\
63 \\
57 \\
89 \\
\cdots\end{array}$ & $\begin{array}{l}\ddot{9} \\
99 \\
99 \\
99\end{array}$ \\
\hline
\end{tabular}

Gost sorfos 1 used cloan o11, in all uthors contuminants woro added.

chumber of fat loun fallupes out of numbur of bearings tostod.

lubricant tost sorios wiff be less then the lifo with the in tho comtaminatod

sorios 1 .

Tost serios $V$ was suspondod aftur $44 k$ terst hours on oach of the logt bearings

due to excessive bearing wear.

\section{CONCLUOING REMARKS}

This paper provides a broad survey of the lubrication of rolling-element bearings. It covers the basic functions of a lubricant, huw to get it to the lubrication what happens if it is not successfully applied. Types of soph ist icated under-race rout ille grease or splash methods to the nore Emphas is is on - race lubrication and cooling techniques are discussed. methods of lubrication. For ball bearings logy ard limitations of the various tapered-roller bearings, great gains have, cylinsrical roller bearings, and their speed capabilities. Under-race lubricetion in the last decade to extend to such high speeds that a naterial and ubrication now allows rellable operation fracture) has become the limiting factor. method of erature limitations of rolling-element bearings are less related to itself. The use of under-race and temperature linitations of the lubricant usefui temperatures range by keeping racerace cooling should however, extend the conditions.
cotures range by keeping raceways cooler for better EHD $f 11 \mathrm{~m}$

For very high temperatures, cryogeric temperatures or high vacuum environments, a designer now has sume cho temperatures or high vacuum film lubrication, or lubrication with some of solid film lubrication, transfer however, limited life applications compared of the newer greases. These are, The limits and techniques for jet lubricat proper oil lubrication. ball bearings and tapered-roller for jubrication are fairly well defined for roller bearings has received little attention Jet lubrication of cylinurical satisfactorily used for both large attention in recent years, but is being very turbine engines.

stationary applications may require rols, efther in transportation systems or in in a vacuum environment for require rolling-element bearings to operate reliably is proposed, but further test ing is periods of time. A wick lubrication system The effects of EHO lubrication and the cunseque its long term operation. thickness have become understoution and the cunsequence of marginal EHO predict performance and life of rolling point that they can be used to better diaynosing lubrication-related bearing-elentent bearings and to a id in chemical interactions, where thearing fallures. However, the effects of values, is an area requiring better understanding asperity contact at low 
1. Grubin. A.N.. "Fundamentals of the Hyurodynanis Theory of Hoavily Loaded Cylindrical Surfaces," Invest lyation of the Contact of Machine

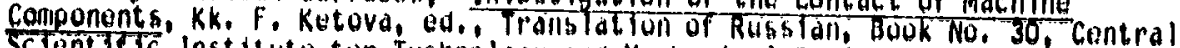
SclentrTe Inst itute tur Techno logy and Mochan lcal Enginetering, Moscow, 1949, Chapter 2. (Avallable from Dopartiment of Sc lentit ic and Industria) Research. $\underset{R=3554 . \text {.) }}{R_{\text {a }}}$

2. Crook, A.W.." "The Lubrtcation of Rollors," Phil losoghical Transactions

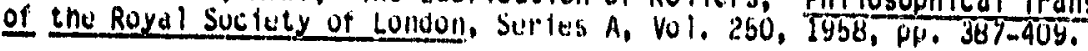

3. Hanruck, B.J. and Dowsun, U., "I suthermal Elastuhyarouynamic Lubrication of Puints contacts. Part 11! - Fully Flooded Results, "Juurnal of Lubrication Technology, Vol. 99, No. 2, Auril 2977, NF. 264-276.

4. Anderson, W.J. "Elastuhyurodynantic Lubrication Theory as a Vesign Parameter for Roliting-E lenent Bearings, "NASA TM X-52727, 1970.

5. Scibbe, H.W., "Bearings and Seals for cryogenic Flutas," SAE Paper No. 680550, Oct. 1968.

6. Brewe, O.E., Sclbbe, H.W., and Wisalder, O.W., "Performance of High-Speed Bdll Bearings with Lead and Lead-Alloy-Plated Retdiners in Liquid Hydrogen at 1.2 Million UN, "Journal of Lubrication Technology, Vol. 96, No. 3,

7. Wiison, D.S., et al., "The Development of Lubricants for High Speed Rolling Contact Bearings Operat ins at $2200 \mathrm{~F}$ Tenperature, "WAOC-TR-59-790, Wright Air Development Center, Ohio, Dec. 1959.

8. Bisson, E.E., and Anderson, W.J., "Advanced Bearing Technology," NASA $S P-38,1964, P P .203-259$ and 351-370.

9. Campbell, M.E., Loser, J.B., and Sneeyas, E., "Solid Lubricants," NASA $S P-5059,1966$.

10. Scarlett, N.f., "Use of Grease in Rolling Bearings," Proceedings of the Institution of Mechanical Engineers, Vol, 182, Part 3A, 1967-1968, 00. 585-593.

11. Oyson, $A_{.}$, and wilson, A.R., Film Thicknesses in Elastohydrouynanic Lubrication of Roliers by Greases, "Proceedings of the Institute of Mechanical
Engineers, Vol. 184, Part 3F, 1969-1970, pp. I11.

12. McCarthy, P.R., "Greases," Interdisplinary Approach to Liquid Lubricant Technology, NASA SP-318, 1973, pp, 137-185.

13. Booser, E.R., "Grease Life Furecast for Ball Bearings," ASLE Preprint No. 74AM-7B-2, May 1974.

14. Matt, R.J., and Giannotti, R.J., "Pertomance of High Speed Ball Bearings with jet oil Lubrication," Lubrication Enufneering, Vol. 22, No. 8 , Aug. 1966, Pp. 316-326.

15. Miyakawa, Y., Seki, K., and Yokoyamia, M., "Study on the Performance of Ball Bearings at High UN Values, "NAL-TR-284, Nat fonal Auruspace Lab., Tokyo,
Japan, 1972. (NASA TTF-15017, I973). 
16. Anderson, W. J. . Macks, E.F., and Nemeth, Z.N. "Comparison of Parformance of Experimental and Convent ional Caga Designs and Materials ror 76-Mill imator-Bore Cylinaircal Roller Bearings at. High Spougs," NASA Report. 1177. 1954.

17. Zaretsky, F.V.. Stgrer. H., and Bamberger, G.N., "Operat ing Limitations

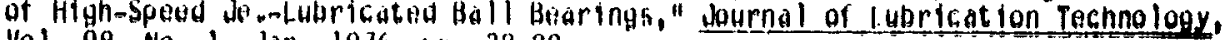
Vol. 98, No. L, Jan. 1976, $\mu \mu, 3 ?+2$ ? 9 .

18. Parker, R.d. alld Signur, H.R., "Lubricatio. if High-Spega, Large Bore

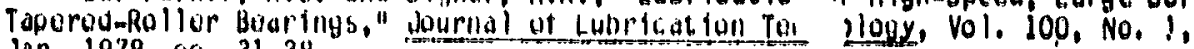
Jan. 1978, $\rho 9.31-38$.

19. Brown, P.F. "Bearlnys and Vampors for Advanced Jet Eng ines," SAE Paper No. 700318, Apr. $19 \%$.

20. Holmes, P.W., "Evaluation of Drillea Ball Bourings at UN Valuas to Three Million," NASA CR-2UO4, and NASA CR-2006, 1972.21. Signur, H., Banberyer, E.N.. and 2aretsky, E.V., "Parametric Study of the Lubrication of Thrust Lodded 120-mo Bore Ball Bearings to 3 Mill ton UN, "Journal of Lubrficat fo. Technology, Vol. 96, No. 3, July 1974, pp. 515-524.

22. Brown, P.F., et al., "Nainshat t High Specu Cylinarical Roller Bearings for Gás Turbine Englins," PWA-FR-8015, Pratt a Whitney Atrcraft Group, West Palm Beach, Fla., Apr. 1977.

23. Schuller, F.T., "Operating Characteristics of a Large-Bore Roller Bearing to Speeds of $3 \times 10^{6}$ ON," NASA TP-1413, 1979.

24. Schuller, F.T., and Signer, H.R., "Effect of Three Lubrication Methods on the Characteristics of a High-.Speed 35-Millimeter-Bore Ball Bearing," NASA TP-in process, 1980.

25. Lemanski, A.J., Lenski, J.W., Jr., "and Urago, R.J., "Design, Fabrication, Test, and Evaluation of Spiral Bevel Support Bearings (Tapered Roller)." USAAMRDL-TR-73-16, U.S. Army Aviation Materials Research and Development Lab., fort Eustis, VA., 1973. (AU-769064)

26. Orvos, P.S. and Dressler, G.J., "Tapered Roller Bearing Development for Atrcraft Turbine Engines," AFAPL-TR-79-2007, Air Force Aeropropulsion Lab., Wright-Patterson AFB, Onio, Mar. 1979.

27. Parker, R.J., Pinel, S.l., and Signer, H.R., "Perforilance of Computer Optimized Tapereu-Rolier Bearings to 2.4 Million ON," Paper for presentation at the 1980 ASME-ASLE Joint Lubrication conference, San Francisco, Calif., Aug. 18-21, 1980.

28. Bamberyer, E.N., "Materials for Rolling Element. "ings, "Paper for presentation a the 1980 ASME-ASLE Joint Lubrication Confere 2, San Francisco, Calif., Aug. 18-21, 1980.

29. Rosenlieb, J.W., "Etheryency and Microtog Lubrication and Cooling of Bearings for Army Helicopters," SKF-AL.77TO21. SKF Industries, Inc., King of Prussia, Pa., Jan. 1978. (NASA CR-13519b).

30. Talllan, et al. "Lubricant Films in Rolling Contact of Rough Surfaces," ASLE Transactions, Vol. 7 , No. 2, Apr. 1964, pp. 10y-126.

31. Harris, T.A., Rulling Bearing Analysis, Wiley, New York, 1966, p. 400.

32. Tallian, T.E., "On Compet ing Fallure Modes in Rolling-Contact," ASLE Transactions, Vol. 10, 1967, of. 418-439. 


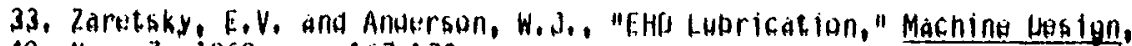
Vol. 40, Nov, $7,1968, \mu \rho, 167-173$.

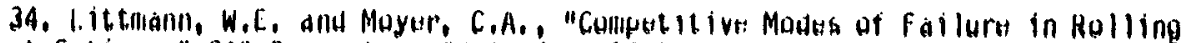
Contact Fatigug," SAF Paper No, d20 $\mathrm{A}_{1}$, lan. I963.

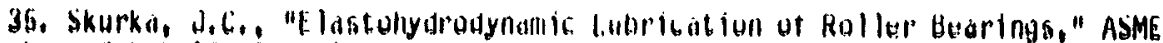

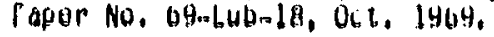

36. Bamberyor, E.N., ot al. "hife Adjustinent Factors for Ball ana Rollor Boarings - An Enylnourliny dessign Guide, "Allerican Soctaly or Mechantcal Eng ineers, Nuw York. 1971.

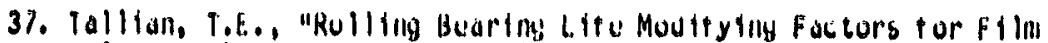
Thicknoss, Surt abe Rouglnues and Friction, "Paper for prosentation at the 1980

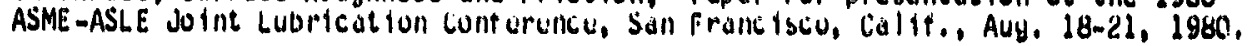

36. Llu, J.Y., Tallian, T.E., alla Mccoul, J.L., "Dependence of Bearing Fat igue Lifo an Filim Thtekness to Surtace Rouglness Rat 10," ASLE Transactions, Vol. 18, No, 2, 1976, 04. 144-152.

39. Crecelilus, W.J., "User's Manual for Steady State and Transient 1 iernal And lysis of a Shatt-Beariny Systeti (SHABERTH), ARBRL-CK-00386, SKF Industries. inc., King of Prussta, Pa., Nov. 1978. (AU-AD64150, AU-E.430167)

40. Kleckner, R.J., Pirvics, J., allu Castelli, V., "High Speed Cylindrical Rolling Element Bearing Analys is "CYBEEA" - And lyt ical Formulation, "ASME Paper No. 79-Lub-35, Oct, 1979.

41. Pirvics, J., "Computerized Analys is and Design Methodology for Rollingmelement Bearing Load Support, "Paper for presentation at the 1980 ASME-ASLE Joint Lubrication Conference, San Francisco, Calif., Aug. 18-21, 1980.

42. Russe11, T.E. and Clark, J.C., "Analytical and Experimental Determination of Surface Finish Eftects on the EHO Perfornance ot Ball Bearings," ASLE Transactions, Vo1, 22, No, 3, July 1979, pp. 286-292.

43. Fitzsimons, B. and Clevenyer, H.U., "Contaminated Lubricants and Tapered Roller Bearing Wear," ASLE Transactions, Vol. 20, No, 2, Apr. 1977, pp. 97-107.

44. Okamoto, J., Fujila, K., and Toshioka, T., "Etfects of solid Particles in 011 on the Life of Ball Bearings, "Jurnal of Mechanical Engineering Laboratory, Tokyo, Vol. 26, No. 5, Sep. 1972, pp. 228-238. (NASA TT F-15653, 1974).

45. Dalal, H., et al. "Final Repurt un Proyression ot Surface danlage in Rolling Cuntact Fatigue," SKF-AL74T002, SKF Industries, Inc., King of Prussia, Pa., Feb. 1974. (AD-780453).

46. Loewenthal, S.H. and Noyer, D.W., "Fill.watior Effects on Ball Bearing Life and condition in a contantinated Lubricant, "Lurn il of Lubrication Technology, Vol. 101. No. 2, Aur. 1979, pp. 171..17..

47. Lynch, C.W. and Cooper, R.B., "The Deve:opnent or a Three-Micron Absolute Main 011 Filter for the T53 Gas Turbine," Jurnal of Lubrication Technology, Vol. 93, No. 3, July 1971, $4 \mu .430-436$. 
APPENIIIX - ¿YMBOLLS

a

n

c

f

6

$H_{m i n}$

n

k

$P_{\mathrm{a}}$

$P_{s}$

$r$

$R_{x}, R_{y}$

U

u

$w_{p}$

$\Lambda$

$\mu_{\mathbf{d}}$

$v$

o

01,02

subscripts

1. 2

$x, y$

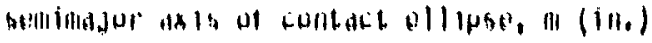

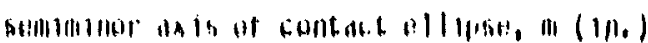

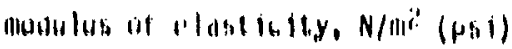

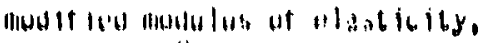

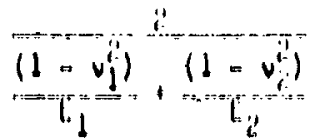

We foull :1010

normal appllou loas, $N(10)$

stinenstonless material parancter, $L^{\prime} / P_{s}$

dimensfonless minfinum 11 lm thickness, $n / R_{x}$

flian thichlless, III (11\%.)

ellipltoity pardfleter, a/b

anbfent pressure, $N / \mathrm{mi}^{2}$ ( $\left.p \mathrm{~s} 1\right)$

asyniptotic isoviscous pressure, $N / m i ?$ (psi) (Ret, 3)

radius of curvature, III (111.)

effective radius of curvalure, in (111.)

$\frac{i}{R_{x}}=\frac{1}{r_{1 x}}+\frac{1}{r_{2 \lambda}} ; \frac{1}{R_{y}}=\frac{1}{r_{1 y}}+\frac{1}{r_{2 y}}$

dithensionless sfeed paranceter, $\left(u_{\mu_{a}}\right) /\left(E^{\prime} R_{x}\right)$

surface velocity in $x$ direction, $\mathrm{m} / \mathrm{sec}(1 \mathrm{n}, / \mathrm{sec}$ )

dimensionless load parameter, $F /\left(E^{\prime} R Z_{x}\right)$

lubricant tilm paraneter, $h / 0$

dynamic viscosity, $N$ sec/mi2 (1b sec:in, $\left.{ }^{2}\right)$

Poisson's ratio

composite surtace rouyhness, microneters $(\mu \mathrm{in.})$

surtace roughness of bodies 1 and 2 , infironeters (uin.)

bodies 1 and 2

coordinate directions 